\title{
Silicified microbiota from the Paleoproterozoic Dahongyu Formation, Tianjin, China
}

\author{
Min Shi, ${ }^{1}$ Qing-Lai Feng, ${ }^{1}$ Maliha Zareen Khan, ${ }^{1}$ Stanley Awramik, ${ }^{2}$ and Shi-Xing Zhu ${ }^{3}$ \\ ${ }^{1}$ State Key Laboratory of Geological Processes and Mineral Resources, China University of Geosciences, Wuhan, 430074, China 〈shimin@ @ cug.edu.cn〉, \\ 〈qinglaifeng@cug.edu.cn〉,〈mallu786@hotmail.com〉 \\ ${ }^{2}$ Department of Earth Sciences, Preston Cloud Research Laboratory, University of California, Santa Barbara, CA 93106, United States \\ 〈awramik@geol.ucsb.edu〉 \\ ${ }^{3}$ State Key Laboratory of Biogeology and Environmental Geology, China University of Geosciences, Wuhan, 430074, China 〈1404063125@qq.com〉
}

\begin{abstract}
Cherts and silicified dolostones of the ca. 1600 Ma Dahongyu Formation (uppermost Changcheng Group) from North China contain well-preserved microfossils. Cyanobacteria filaments and coccoids dominate the studied Dahongyu microbiota in the Jixian section. These microfossils show the characteristics of endobenthic, epibenthic, and allochthonous microfossils, which illustrated well a vertical distributional view of an intertidal microbiota. Large numbers and size of allochthonous microfossils are the distinguishing characteristics of this new microbiota. A few of these possess ornaments or odd morphology, which suggest their potential eukaryotic nature. Through regional comparisons, it is revealed that there was significant regional disparity within the Yanshan Basin of microbiotas during deposition of the Dahongyu Formation. The newly studied Dahongyu microbiota is similar to the microbiota from the underlying Changcheng Group, with only slight differences. The absence of typical eukaryotes and the emergence of unique microfossils (especially small fusiform microfossils) make the Dahongyu Formation and the subsequent strata of the Jixian Group distinct from contemporaneous eukaryote-bearing strata.

In the Dahongyu assemblage, 19 species were recognized, six species were identified informally and seven species were identified in open nomenclature. One new taxon of microfossil was described: Xiaohongyuia sinica Shi and Feng new genus new species.
\end{abstract}

\section{Introduction}

The so-called "boring billion" ( 1.8-0.8 Ga) was characterized by environmental stability and its conditions are thought to have delayed eukaryotic diversification (Holland, 2006; Planavsky et al., 2014). Tectonically, this period was far from boring, since it involved the activity of the Columbia and Rodinia supercontinent (Zhang et al., 2012). Moreover, the evolution of Earth's biosphere, atmosphere, and hydrosphere is thought to tie with the continental movements (Campbell and Allen, 2008; Santosh, 2010; Young, 2013). Correspondingly, recent studies have revealed that obvious chemical and geological changes occurred during the "boring billion" (Guo et al., 2012). Javaux et al. (2013) proposed that the "boring billion" was actually an "exciting time" for early eukaryotes, but direct taxonomic evidence is not very common in the early "boring billion" (Knoll et al., 2006; Butterfield, 2007). Based on the study of microfossils from ca. 1600 Ma strata, Yin (1985) proposed that an obvious morphological differentiation had occurred. However, subject to photographic limitations, demonstrating characteristics of morphological differentiation are blurred. In order to portray the biological community during this critical era, the unmetamorphosed and classic Jixian section was selected for a systematic study of microfossils from the Dahongyu Formation. This involved the preparation of 914 thin sections of chert samples for examination. Consequently, a large number of microfossils were recovered.

\section{Geological setting, stratigraphy, and age}

The Yanshan Basin in North China is one of the rift basins that formed during the break-up of the Columbia supercontinent (Lu et al., 2002, 2004; Zhang et al., 2012). Unmetamorphosed successions of Proterozoic sedimentary rocks are widely exposed in this basin. The studied Jixian section is located in the middle of the Yanshan Basin (Fig. 1) and exceeds 10,000 m in thickness. In ascending order, it has been divided into the Changcheng, Jixian, Huailai, and Qingbaikou groups, with ages ranging from 1670 to $850 \mathrm{Myr}$ (Li et al., 2011) (Fig. 2). In the lower part of the Changcheng Group, clastic rocks are dominant. Carbonates initially emerged in the upper part of the Changcheng Group and dominated the sediments in the Jixian Group. Clastic rocks appeared again in the upper part of the Jixian section, dominating the Huailai Group and the Qingbaikou Group.

The Dahongyu Formation was the last sedimentary formation of the Changcheng Group. During Dahongyu deposition, wide-spread and long-standing volcanic activities occurred (Ren, 1987). Volcanic materials and terrestrial deposits are ubiquitous in the Yanshan Basin and exhibit obvious 


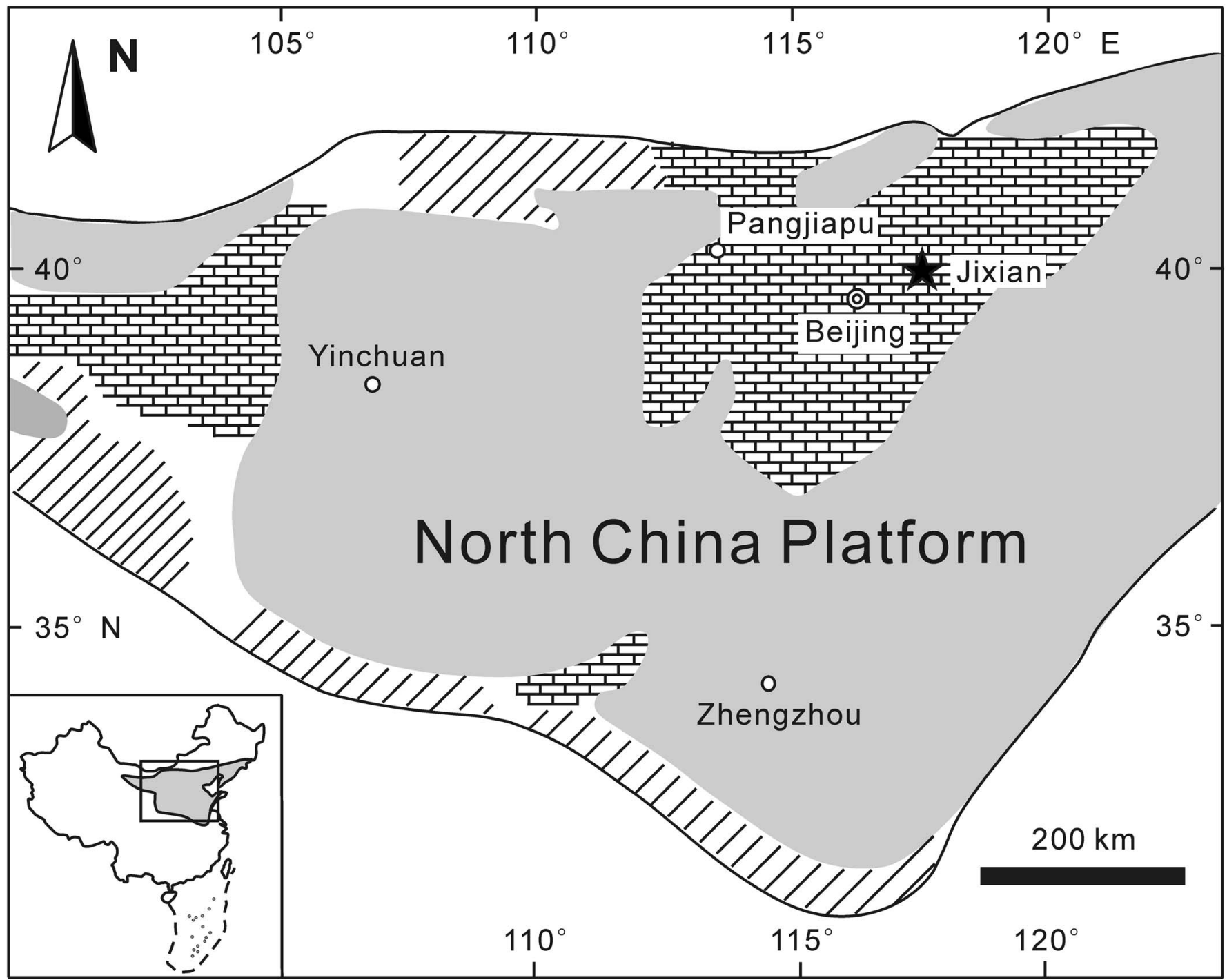

Non-deposition or erosion 臣空 Shallow platform sediments

Transitional deeper-water sediments

Figure 1. Geographic location of the Jixian section and simplified paleo-geographic map during this time of the North China Platform (modified from Chu et al., 2007).

regional disparity. From the east to the west of the Yanshan Basin, volcaniclastic rocks thin to pinch out, and conversely carbonates become dominant. In the east of the basin, strata are $675 \mathrm{~m}$ thick and dominated by terrestrial clastic rocks (quartz sandstone, sandy shale, and dolomitic sandstone). In the Jixian section located in the middle of the Yanshan basin, strata are $408 \mathrm{~m}$ thick and composed of quartz sandstones, trachytes, and carbonates. In the Pangjiapu section located in the west of the Yanshan basin, strata are $171 \mathrm{~m}$ thick and dominated by carbonates, with volcanic materials and detrital rocks absent. Based on these characteristics of sediment distribution, $\mathrm{Xu}$ et al. (2002a) proposed that the provenance was in the east of the Yanshan Basin. In the Jixian section, the Dahongyu Formation conformably overlies the Tuanshanzi Formation and unconformably underlies the Gaoyuzhuang Formation and comprises three sedimentary members: (1) the first member is composed of terrestrial clastic rocks, quartzite sandstones, feldspar quartzite sandstones, and dolomitic sandstones; (2) K-rich trachytes, K-rich tuffs, and volcanic breccias are the chief sediments of the second member; and (3) the third member mainly comprises various carbonates, accompanied by banded cherts (Fig. 2).

The third member of the Dahongyu Formation is $115 \mathrm{~m}$ thick, with a basal pebbly sandstone unit that overlies the trachytes of the second member. Thin beds of gray sandy dolostones and argillaceous-arenaceous dolostones followed upward, accompanied by banded cherts. Beds of dolostones thicken upwards and Petaliforma stromatolites appear. The upper part is mainly gray to dark-gray, thin-layered argillaceous-arenaceous dolostones with rhythmicly distributed banded cherts and tuberous stromatolites. The third member ends with 


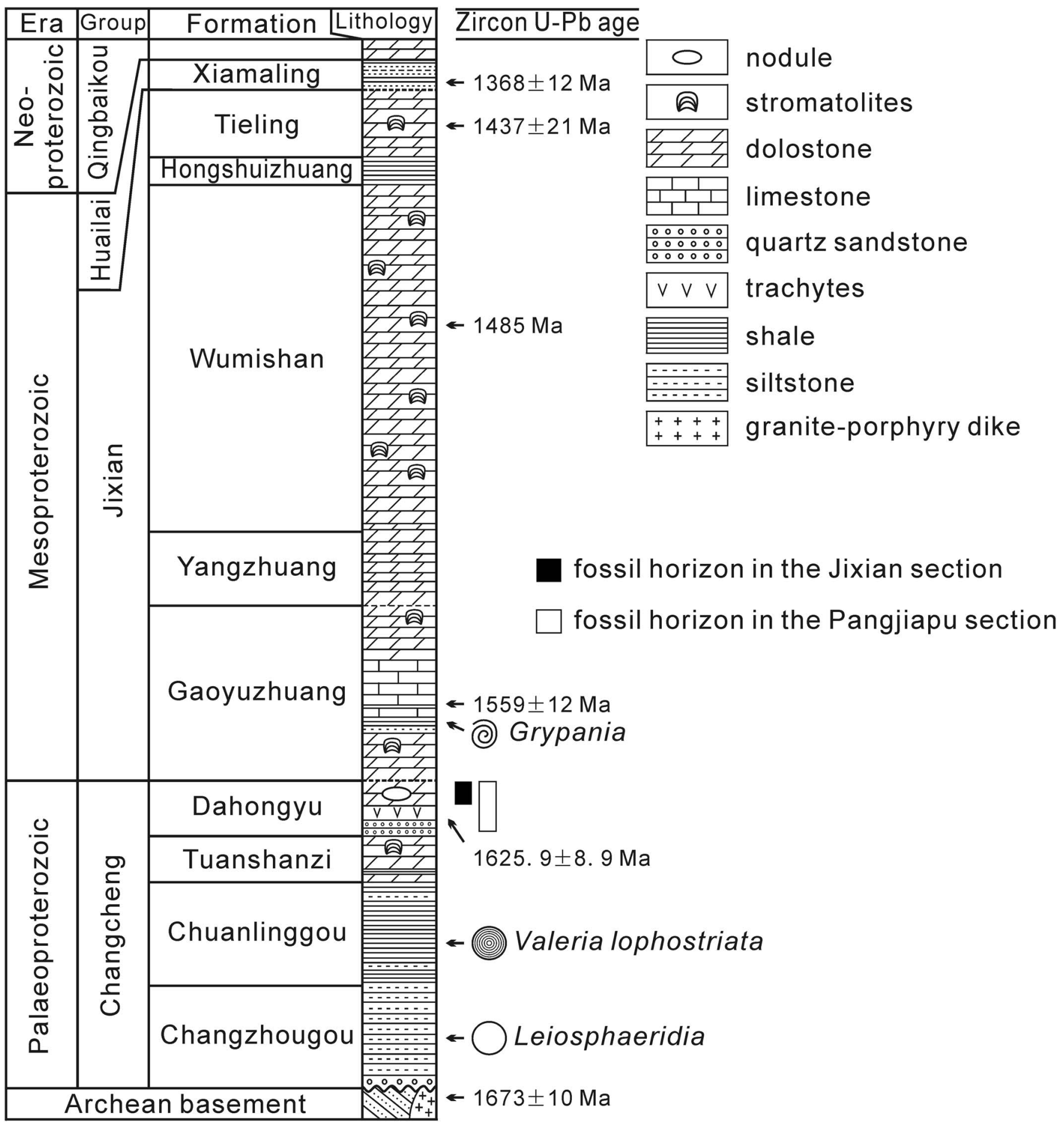

Figure 2. Stratigraphic columns of the Proterozoic Jixian section with geo-chronological constraints. Geo-chronological data: Gao et al. (2008), Gao et al. (2009), Li et al. (2009, 2010, 2011, 2014), and Su et al. (2010). Grypania: Yan and Liu, 1998; Valeria lophostriata: Peng et al., 2009; Leiosphaeridia: Lamb et al., 2009.

thick-bedded silicified dolostones. Conophyton stromatolites at the top of the Dahongyu Formation are truncated by the overlying Gaoyuzhuang Formation. According to sequence stratigraphic information and stromatolites, the third member is inferred to have been deposited during the transgression of a sea. Unfortunately, the regressive sequence and related highstand systems tract is missing. Samples were systematically collected from the third member and most fossiliferous samples were concentrated at the upper part of the third member.

Precise chronological frameworks of the Proterozoic strata in the Yanshan basin have been established over recent years (Lu and Li, 1991; Gao et al., 2008, 2009; Li et al., 2009, 2010, 2011, 2014; Su et al., 2010) (Fig. 2). The samples were collected from the upper part of the Dahongyu Formation because cherts 
mostly crop out from dolostones of the third sedimentary member. SHRIMP U-Pb zircon ages of $1625.9 \pm 8.9 \mathrm{Ma}$ and $1559 \pm 12$ Ma have been obtained from the second sedimentary member of the Dahongyu Formation and the Gaoyuzhuang Formation, respectively (Gao et al., 2008; Li et al., 2010), demonstrating the age of the third sedimentary member of the Dahongyu Formation to be ca. 1600 Ma.

\section{Materials and methods}

All fossiliferous samples in this research are silicified peloidal arenite sediments that were systematically collected from the dolostone-dominated strata of the third sedimentary member. The sampling point is located $\sim 15 \mathrm{~km}$ north of Jixian County, Tianjin, China (Fig. 1, coordinate: $40.16594^{\circ} \mathrm{N}, 117.47364^{\circ} \mathrm{E}$ ). At the outcrop scale, silicified peloidal sediments are mottled black to brownish gray in color. Uncompacted peloidal grains suggest that these materials had undergone early diagenetic cementation. These peloidal deposits are heterogenous in texture with organic-rich peloids surrounded by organic-poor silicious cements. Microfossils are abundant inside peloidal grains. Thirty-two chert samples were collected and two petrographic thin sections were made for each of the samples. Seventeen samples contain well-preserved microfossils. Subsequently, fifty thin sections were prepared for each sample and abundant microfossils were recovered, measured, and photographed using biological microscope Leica DM 5500 and Leica Application Suite 4.0.0 software.

Repository and institutional abbreviation.-All illustrated specimens are in petrographic thin sections of chert. Locations and position coordinates for each specimen in this study are stored with the thin sections in the State Key Laboratory of Geological Processes and Mineral Resources, China University of Geosciences, Wuhan, China.

\section{General characteristics of the newly studied Dahongyu microbiota}

This is the first time that well-preserved silicified microfossils have been recovered from the Dahongyu Formation of the Jixian section. In total, 19 species were recognized, six species have been identified informally and seven species have been identified in open nomenclature (Table 1). Simple cyanobacterial filaments and coccoids are dominant elements, but most diversity is contributed by rare taxa. By observing their preserved state and living habits, colonially preserved microfossils and isolated individuals were recovered separately.

Colonies.-Colonially preserved microfossils in the new microbiota are mostly simple cyanobacteria, including hormogonian and chroococcacean. Based on their state of preservation and living habit, they are mainly recognized as builders that contributed to mat-building.

Filament colonies.-Filament colonies, including filamentous trichomes and sheaths, are abundant. These filaments exhibit differing living habits; some growing upwards, some were randomly scattered in the matrix, and others grew parallel to the bedding plane. Based on their morphology and size, two genera and nine species are recognized: Oscillatoriopsis (O. obtusa, $O$. amadeus, $O$. longa, and $O$. princeps) and Siphonophycus (S. thulenema, S. septatum, S. robustum, S. typicum, and S. kestron).

Oscillatoriopsis.-Filaments of Oscillatoriopsis form macroscale aggregates as ubiquitous elements (Fig. 3.1-3.3). Based on their distributional pattern in the matrix, three different aggregates have been recovered (Figs. 3.1-3.3, 4.2). These three aggregates exhibited very different features.

The first Oscillatoriopsis aggregate is composed of $O$. obtusa and $O$. amadeus (Figs. 3.1, 4.2, aggregate 1; specimens could only be assigned to particular species based on measurement because their diameters are distributed in a continuous zone). These trichomes, which are arranged closely in twos and threes, have been observed to be parallel and bend together in the same region. Their arrangement suggests that they may have been bounded together by a common envelope during the process of bending. The tentative multi-trichome nature is comparable with Eoschizothrix composite, which has been reported from the overlying Gaoyuzhuang Formation (Lee and Golubic, 1998).

The second Oscillatoriopsis aggregate is formed by morphologically uniform filaments (Figs. 3.2, 4.2, aggregate 2), which are $O$. amadeus, $O$. longa, and $O$. princeps. These filaments are short, flexible, and do not possess tapering ends. Their diameters vary from $9.8 \mu \mathrm{m}$ to $27.3 \mu \mathrm{m}$ and form a single main diameter-frequency distributional peak, which is $13-19 \mu \mathrm{m}$ (Fig. 4.2, aggregate 2). This characteristic indicates that these filaments may have belonged to the same biological taxon.

Filaments of the third Oscillatoriopsis aggregates are variable in size but uniform in morphology (Fig. 3.3). Oscillatoriopsis longa and $O$. princeps are the key elements of this aggregate. Some $O$. amadeus filaments also emerged (Fig. 4). Their diameters varied from $8.2 \mu \mathrm{m}$ to $35.8 \mu \mathrm{m}$ and formed several distributional peaks of diameter-frequency (Fig. 4.2, aggregate 3 ). This nature suggests that they could belong to different biological taxa.

Siphonophycus.-Five morphologic species of Siphonophycus (S. thulenema, S. septatum, S. robustum, S. typicum, and $S$. kestron) have been identified in the studied assemblage (Figs. 5, 6). As the most abundant filaments, Siphonophycus mostly appears in dense or loose aggregates and only a few emerge as individuals. Three different types of aggregates have been recovered according to their distributional pattern in the matrix (Figs. 5.2, 6).

The first Siphonophycus aggregate is dominated by S. thulenema, which usually arrange into small bundles of aggregates (Fig. 5.2, aggregate 1; Fig. 6.1, 6.2). Siphonophycus septatum is occasionally present within these small aggregates as a rare member (Fig. 6.2 arrow). Most $S$. thulenema filaments extended parallel to the bedding plane or along with the outer edge of a pelletoid (Fig. 6.1, 6.2). They do not exhibit an upward trend in growth direction, which may indicate that they were not photosynthetic organisms, or that their environment was not affected by sunlight. These aggregates are distributed in 
Table 1. Synoptic listing of microfossil taxa from the Dahongyu Formation, Jixian section, indicating their size ranges and morphological characteristics. A. umishanensis $=$ Asperatopsophosphaera umishanensis, N. = Number, L. = Length, W. = Width.

\begin{tabular}{|c|c|c|c|c|c|}
\hline \multirow[b]{2}{*}{ Species/Taxa } & \multicolumn{2}{|l|}{ Size } & \multirow[b]{2}{*}{$\mathrm{N}$} & \multirow[b]{2}{*}{ Morphological characteristics } & \multirow[b]{2}{*}{ Figure } \\
\hline & Range & Mean & & & \\
\hline Oscillatoriopsis obtusa & L $2.5-4.5 / \mathrm{W} 3.8-7.7$ & $3.7 / 6.2$ & 28 & Unbranched trichome without sheath; cell width is $3-8 \mu \mathrm{m}$; cell length is smaller than width & Fig. 3.1 \\
\hline Oscillatoriopsis amadeus & L $3-5.5 / \mathrm{W} 8-14$ & $4 / 12$ & 30 & Unbranched trichome without sheath; cell width is $8-14 \mu \mathrm{m}$; cell length is smaller than width & Fig. 4 \\
\hline Oscillatoriopsis longa & L $3.3-6 /$ W 14-24.8 & 3.8/19.1 & 104 & Unbranched trichome without sheath; cell width is $14-25 \mu \mathrm{m}$; cell length is smaller than width & Fig. 3.4 \\
\hline Oscillatoriopsis princeps & L $5-10.5 / \mathrm{W} 25-35.8$ & $7.4 / 29.5$ & 30 & Unbranched trichome without sheath; cell width is $25-50 \mu \mathrm{m}$; cell length is smaller than width & Fig. 3.5, 3.6 \\
\hline Siphonophycus thulenema & W $0.3-0.6$ & 0.5 & 99 & Unbranched, nonseptate and smooth-surfaced tubular filaments; $0.5 \mu \mathrm{m}$ in width & Fig. $6.1,6.2$ \\
\hline Siphonophycus septatum & W $1.0-2.0$ & 1.7 & 57 & Unbranched, nonseptate and smooth-surfaced tubular filaments; $1-2 \mu \mathrm{m}$ in width & Fig. 6.2 (arrow) \\
\hline Siphonophycus robustum & W $2.0-4.0$ & 2.8 & 107 & Unbranched, nonseptate and smooth-surfaced tubular filaments; $2-4 \mu \mathrm{m}$ in width & Fig. 6.5 (arrow) \\
\hline Siphonophycus typicum & W $4.0-8.0$ & 5.5 & 158 & Unbranched, nonseptate and smooth-surfaced tubular filaments; $4-8 \mu \mathrm{m}$ in width & Fig. 6.5 \\
\hline Siphonophycus kestron & W $8.0-16.0$ & 9 & 8 & Unbranched, nonseptate and smooth-surfaced tubular filaments; $8-16 \mu \mathrm{m}$ in width & Fig. 5 \\
\hline Glenobotrydion varioforme & $2.5-6.5$ & 4.5 & 54 & Cell-like units with one to a few spherical or irregular shaped inclusions & Fig. 7.1a, 7.2 \\
\hline Eosynechococcus moorei & L $3.8-7.4 / \mathrm{W} 2-3.5$ & $5.2 / 2.8$ & 22 & Colonially preserved oblong, rod-shaped to ellipsoidal cell-like units. & Fig. 7.1b \\
\hline Coccostratus dispergens & $2.5-6$ & 4.5 & 22 & Colonially preserved spheroidal cell-like units & Fig. 7.3 \\
\hline Gloeodiniopsis sp. & $19-68$ & 27.2 & 100 & Colonially preserved spherical microfossils with thin, transparent, smooth-surfaced flexible wall & Fig. $8.1-8.12$ \\
\hline Tetraphycus gregalis & $2.5-4.5$ & 3.5 & 18 & Tetrads surrounded organic amorphous matrix & Fig. $9.1,9.2$ \\
\hline Coniunctiophycus majorinum & $1.5-5$ & 3.5 & 41 & Colonially preserved small spheroidal to ellipsoidal units of vesicles & Fig. 9.3, 9.4 \\
\hline Clonophycus sp. & $30-57.5$ & 43.5 & 12 & Spherical coenobium & Fig. $9.5-9.8$ \\
\hline Myxococcoides grandis & $11-35$ & 21.5 & 27 & Un-compressed and smooth-surfaced spherical vesicles & Fig. 9.9 \\
\hline Myxococcoides sp. & $7-22$ & 14 & 67 & Un-compressed spherical vesicles & Fig. $7.4,7.5$ \\
\hline Leiosphaeridia spp. & $40-589.5$ & 104 & 273 & Smooth-surfaced spherical microfossils & Figs. $9.10-9.18,10.1-10.5$ \\
\hline Leiosphaeridia minutissima & $31-45$ & 35 & 5 & Smooth-surfaced spherical microfossils with thin cell wall & Fig. 11.6, 11.7 \\
\hline Pterospermopsimorpha sp. & $38.5-126.5$ & 72.2 & 15 & Solitary spherical microfossils with a large, spherical dark inclusion & Fig. 9.19 \\
\hline A. umishanensis & $26.7-55.4$ & 35.5 & 15 & Spherical cells with granular surface & Fig. 10.6-10.9 \\
\hline Dictyosphaera macroreticulata & $40.5-49.5$ & 45 & 2 & Spherical cells with reticulate sculptures on their surface & Fig. 10.10, 10.11 \\
\hline Leioarachnitum sp. & L $8-53 / W 4-27$ & $31 / 15$ & 23 & Fusiform units with a medial split that is parallel to the long axis direction & Fig. 11.1-11.5 \\
\hline $\begin{array}{l}\text { Xiaohongyuia sinica Shi and } \\
\text { Feng n. gen. n. sp. }\end{array}$ & W $15.5-45$ & 29 & 46 & Irregular-shaped microfossils & Fig. 12.1-12.16 \\
\hline Unnamed Form 1 & 76-80 & 78.3 & 3 & Spherical cell with a broken neck-like extension & Fig. 11.8 \\
\hline Unnamed Form 2 & $\mathrm{~L} 41 / \mathrm{W} 25$ & - & 1 & Cell pairs within a common organic wall; outer wall is coarsely granulated & Fig. 11.9 \\
\hline Unnamed Form 3 & L $50 / \mathrm{W} 30$ & - & 1 & Cell pairs without envelope & Fig. 11.10 \\
\hline Unnamed Form 4 & L $39.5-49 / \mathrm{W} 29-32$ & $44.3 / 30.5$ & 2 & Dividing cells & Fig. 11.11 \\
\hline Unnamed Form 5 & $30-34$ & 32 & 2 & Spherical microfossils with a single spine-like structure on its surface & Fig. 11.12 \\
\hline Unnamed Form 6 & L $336 / W 248$ & - & 1 & Vase-like microfossil with a neck-like structure & Fig. 11.13 \\
\hline Unnamed Form 7 & $25-101$ & 63 & 2 & Vesicle with short and loosely distributed spine-like ornamentation & Fig. 11.14, 11.15 \\
\hline
\end{tabular}



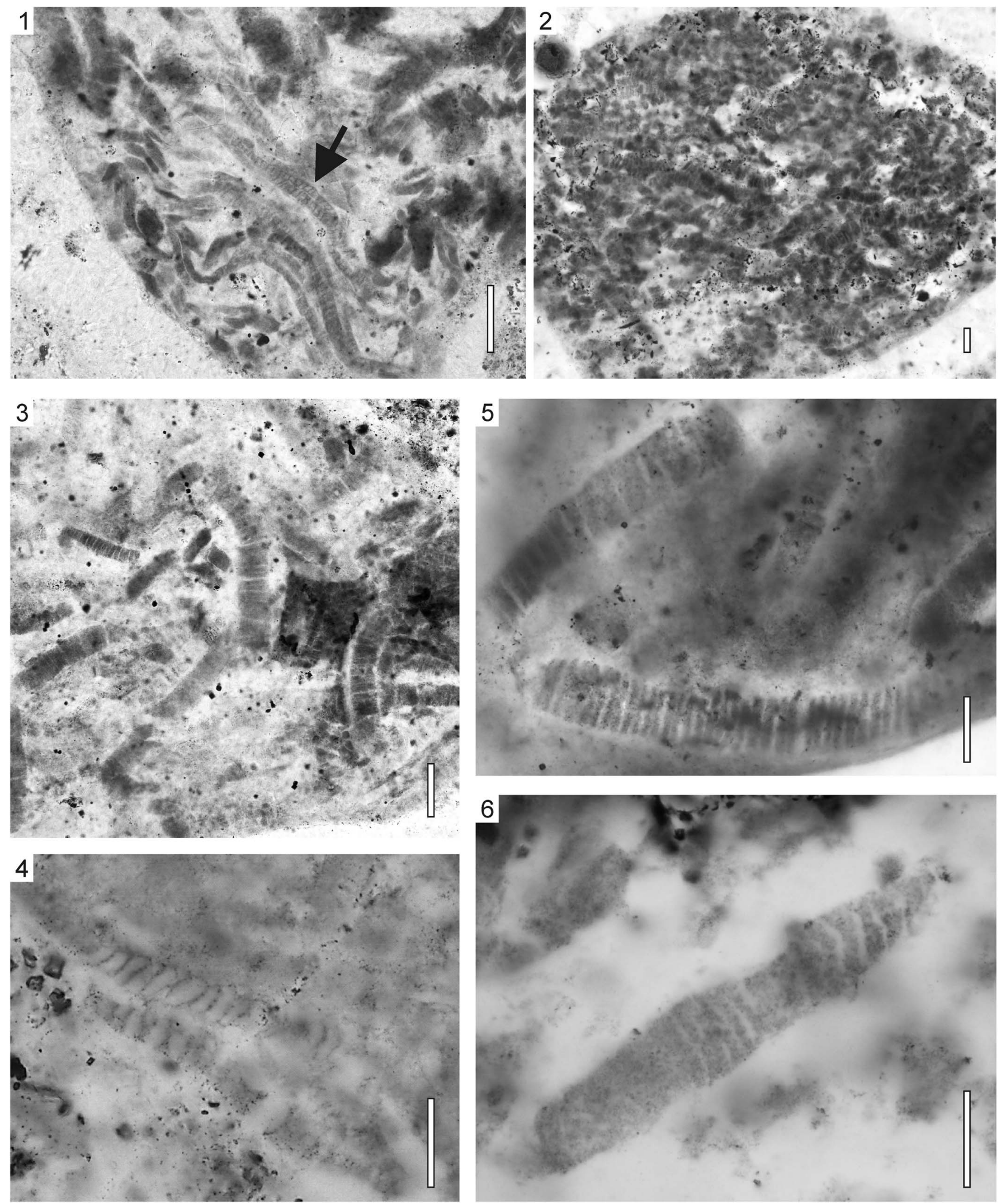

Figure 3. Filaments of Oscillatoriopsis: (1) aggregate dominated by $O$. obtusa: 2012XHYD_6_11; (2) aggregate dominated by $O$. amadeus and $O$. longa: 2012XHYD_5_18; (3) aggregate dominated by $O$. longa and $O$. princeps: 2012XHYD_3_13; (4) O. longa: 2012XHYD_13_17; (5) O. princeps: 2007XHYD_1_2; (6) O. princeps: 2012XHYD_24_10. All scale bars $=30 \mu \mathrm{m}$. 

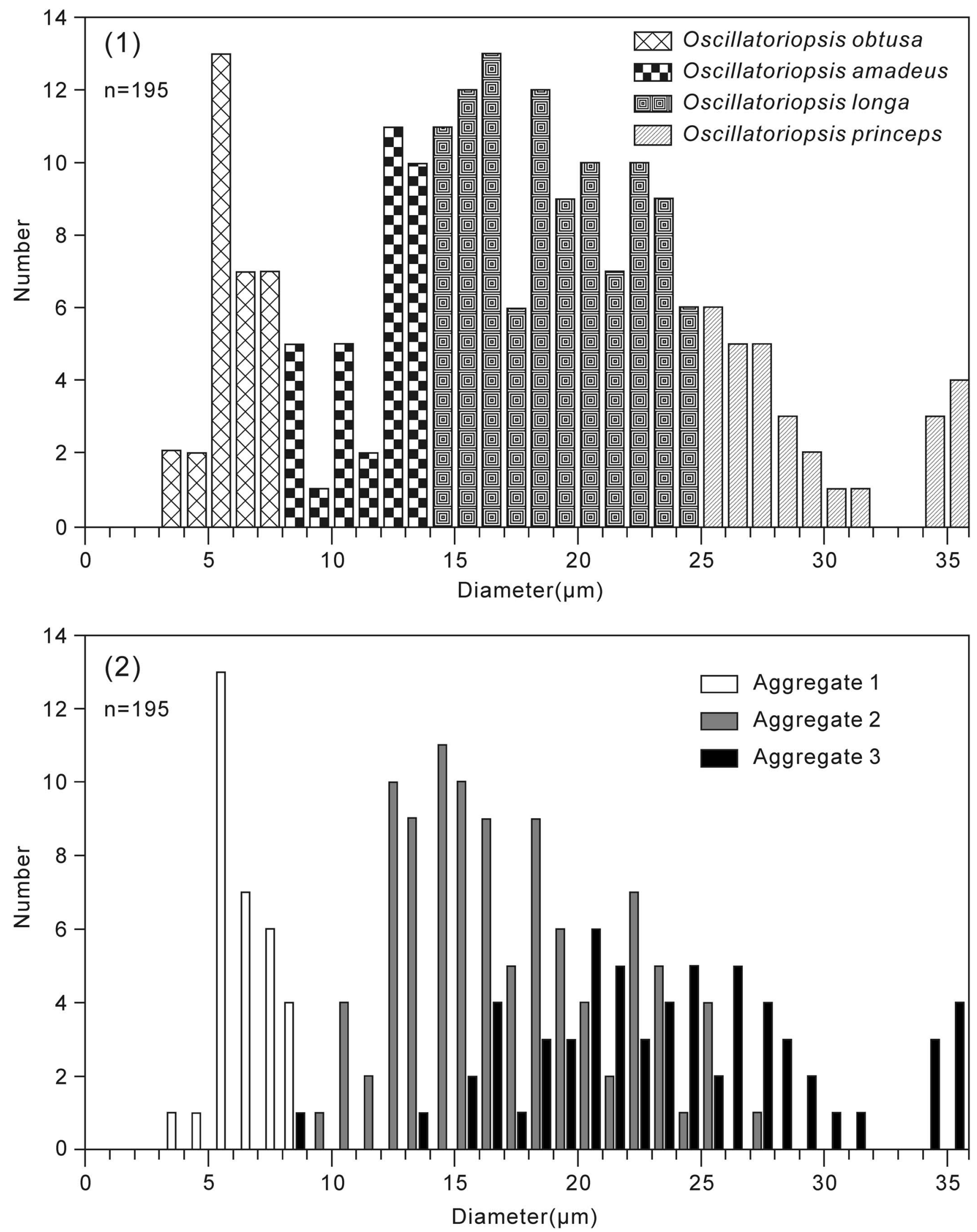

Figure 4. Diameter-frequency distributions of Oscillatoriopsis: (1) total diameter-frequency distribution of all Oscillatoriopsis; (2) diameter-frequency distribution of three different Oscillatoriopsis aggregates. 

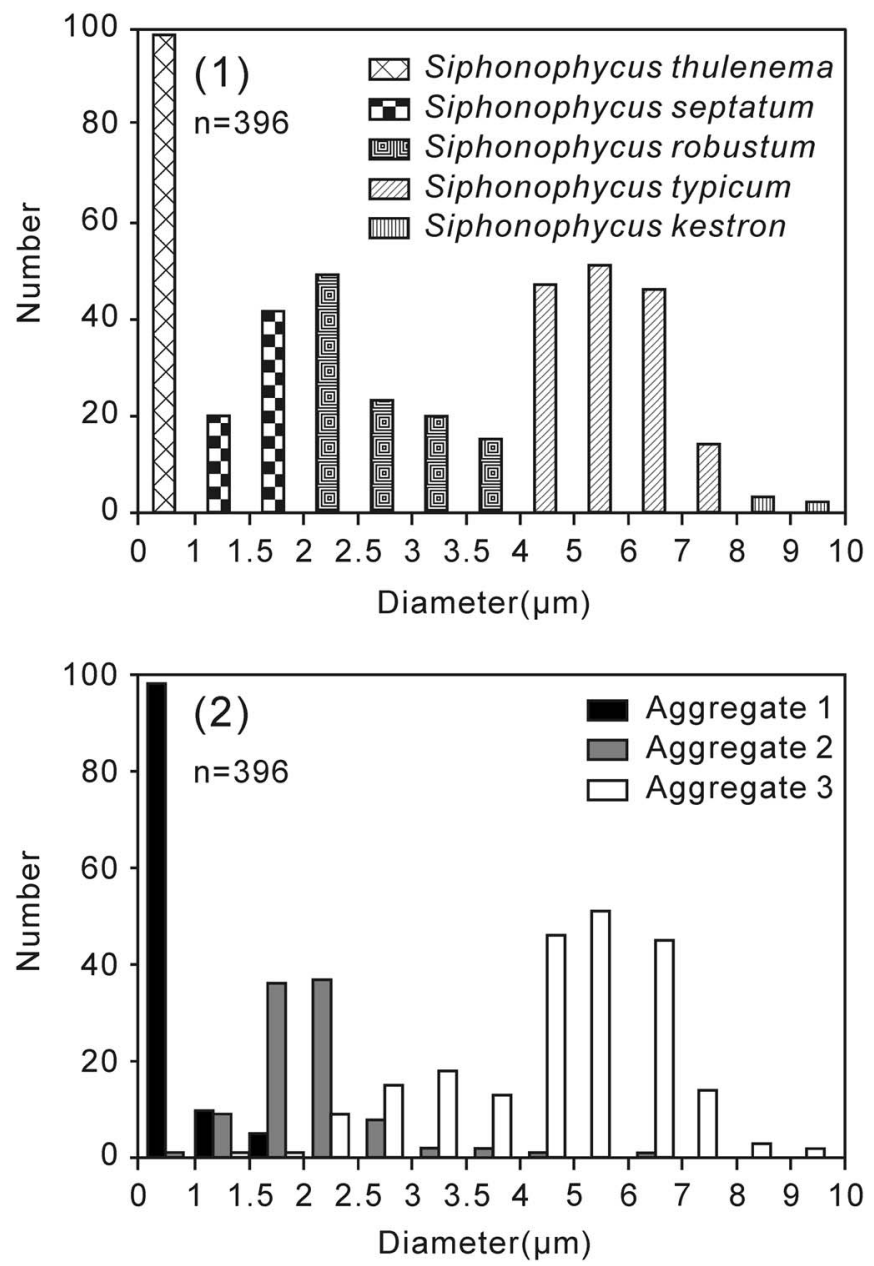

Figure 5. Diameter-frequency distributions of Siphonophycus: (1) total diameter-frequency distribution of all Siphonophycus; (2) diameter-frequency distribution of three different Siphonophycus aggregates.

bundles, which may indicate that they were affected by water flow during their growth.

The second Siphonophycus aggregate is composed of S. robustum and S. septatum, which are common elements and usually appear together to form small aggregates (Fig. 5.2, aggregate 2 ; Fig. $6.3,6.4$ ). These aggregates usually occur within organic-poor matrix, such as cements between pelletoids (Fig. 6.3, 6.4). They sometimes grew along with the outer edge of a pelletoid (Fig. 6.3). Their distribution pattern does not exhibit a particular direction of growth, but exhibits a chaotic state. This phenomenon may suggest that they were nonphotosynthetic organisms, while indicating that they lived in a hydrostatic environment without sunshine.

The third Siphonophycus aggregate is dominated by $S$. typicum, which is the most abundant mat builder in the newly studied Dahongyu microbiota (Fig. 5.2, aggregate 3; Fig. 6.5). In $S$. typicum-dominated aggregates, $S$. robustum is an associated member and participated in mat-building (Fig. 6.5, see arrow). In addition to these two main members, S. septatum and S. kestron are occasionally present. In organic-poor layers, filaments grew upward. In contrast, filaments exhibit a horizontal growth tendency in organic-rich layers. Due to their interactive growth, characteristic rhythms of bright and dark layers were established.

Spherical colonies.-Spherical colonies are not very common in the new microbiota. They do not form a laminar plane because of their small scale. Colonially preserved spheres are generally small in size and have simple morphology. They are densely or sparsely distributed together and form small-scale clusters in the matrix. According to their morphology and size, five species have been recognized and three species have been determined informally: Glenobotrydion varioforme, Coccostratus dispergens, Eosynechococcus moorei, Gloeodiniopsis sp., Coniunctiophycus majorinum, Tetraphycus gregalis, Clonophycus sp., and Myxococcoides sp.

Colonially preserved coccoids are usually small in size and simple in morphology. Inside the matrix, they are densely or loosely distributed together and formed some small-scale clusters. Gloeodiniopsis sp. (Fig. 8), as one of the colonially preserved coccoids, is very well preserved and shows the reproduction procedure of straight splitting (Fig. 8.3). Colonies with regular spherical outlines are typical elements (Fig. 9.3-9.8). Inside the spherical colony, tens or hundreds of cells are arranged densely with or without order. These colonies are comparable with some member of modern cyanobacteria Pleurocapsa and Gloeocapsa, which can lead to the process of multiple fissions and produce baeocytes.

Isolated individuals.-In the Dahongyu microbiota, isolated individuals constitute up to $20 \%$ of the content and contribute to more than half of the diversity. Based on their morphology, we recognized five species, five undetermined species, and seven undetermined forms: Myxococcoides grandis, Xiaohongyuia sinica Shi and Feng n. gen. n. sp., Dictyosphaera macroreticulta, Asperatopsophosphaera umishanensis, Leiosphaeridia minutissima, Myxococcoides sp., Leioarachnitum sp., Leiosphaeridia sp., Pterospermopsimorpha sp., and seven problematic taxa.

These isolated individuals mostly are coccoidal in morphology, accompanied with fusiform microfossils and some irregular morphological microfossils. Spherical types are mostly smooth-surfaced, although ornamented spheres, such as granular-surfaced (Fig. 10.6-10.9) and reticular-surfaced (Fig. 10.10, 10.11) forms are also very common. Besides ornaments, other morphological features, such as longitudinal rupture (Fig. 11.1-11.7), neck-like extension (Fig. 11.8), spine-like structure (Fig. 11.12), vase-shaped morphology (Fig. 11.13), spines (Fig. 11.14, 11.15), and undefined shapes (Fig. 12), also suggest that they belong to different taxa.

The small fusiform microfossil Leioarachnitum sp. has been recovered from the Dahongyu Formation in abundance

Figure 6. Filaments of Siphonophycus: (1) aggregate of S. thulenema, arrow indicates S. septatum: 2012XHYD_47_5; (2) aggregate of S. thulenema: 2012XHYD_47_5; (3) aggregate dominated by S. septatum and S. robustum: 2012XHYD_20_3; (4) aggregate dominated by S. septatum and S. robustum: 2008XHYD_2_1; (5) aggregate dominated by $S$. typicum, arrow indicates S. robustum: 2012XHYD_47_5. Scale bars are (1) 15 $\mu$ m, (2) 10 $\mu$ m, (3) 60 $\mu$ m, (4) $50 \mu \mathrm{m}$, and (5) $35 \mu \mathrm{m}$. 

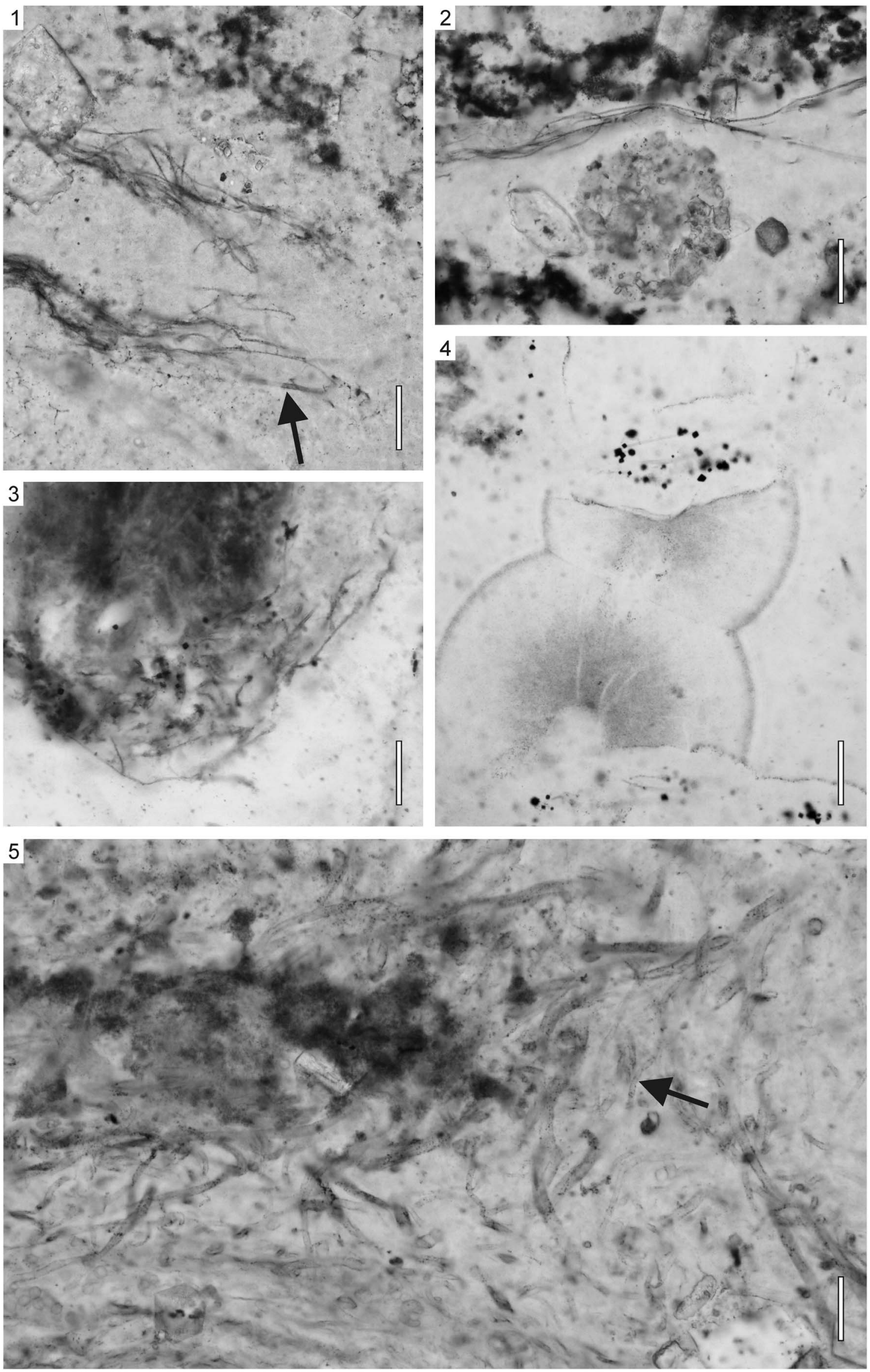

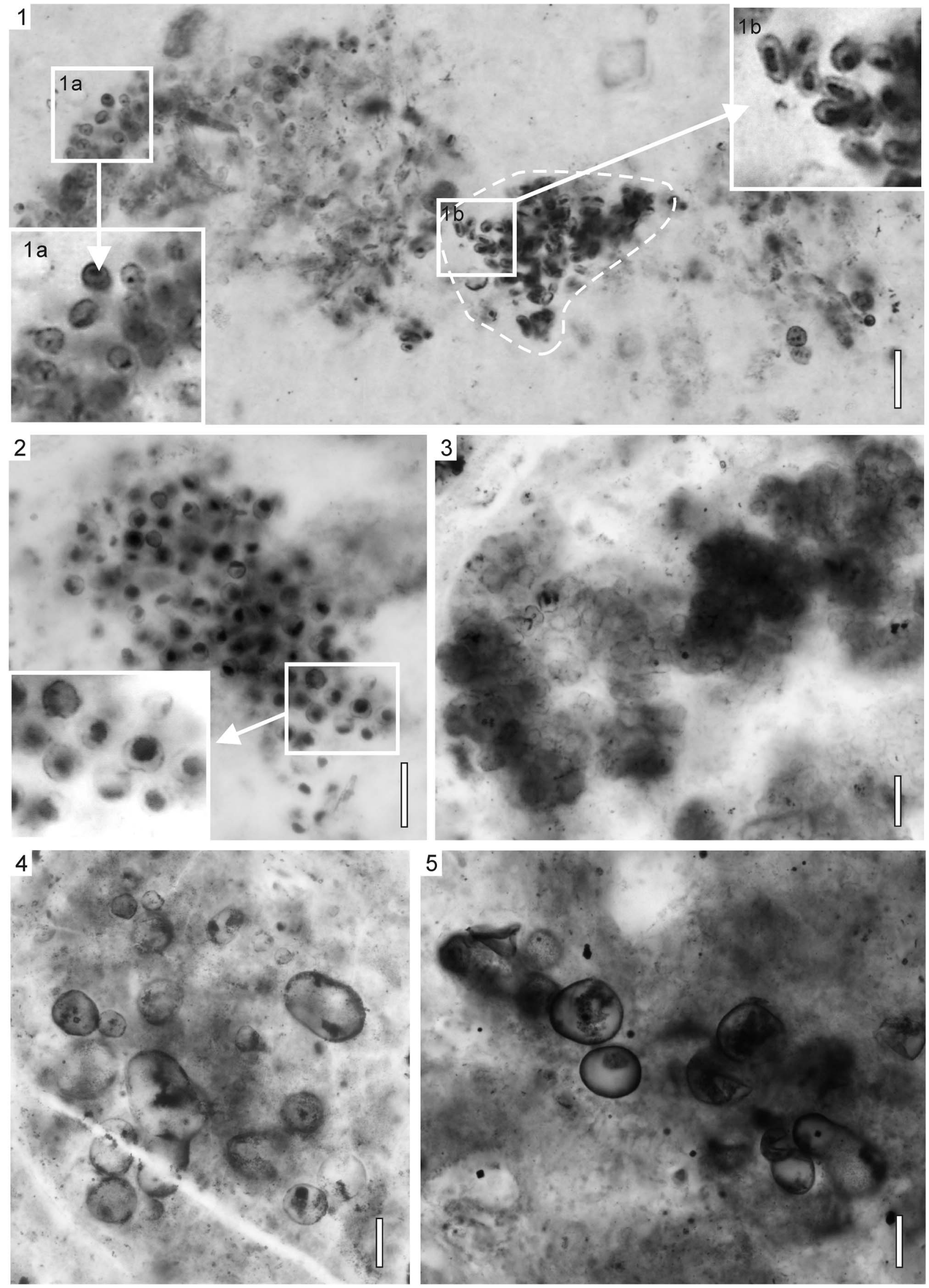
(Fig. 11.1-11.5). These are also widely distributed in the overlying Jixian Group (Cao, 2005; Shi et al., 2014). Most specimens of these new small fusiform microfossils are preserved as a complete envelope with a longitudinal rupture (Fig. 11.1-11.3). Additionally, some specimens have been found without the longitudinal rupture (Fig. 11.4, 11.5). The emergence of these specimens without rupture may demonstrate the state, before excystment, of these small fusiform microfossils. Therefore, small fusiform microfossils are probably different micro-organisms from those specimens of the Chuanlinggou Formation. The medial split, which indicates excystment, could attribute them to the eukaryotic domain.

Xiaohongyuia sinica Shi and Feng n. gen. n. sp. is a new taxon with irregular morphology, including but not limited to binary, lageniform, triangle, calabash, and chain-like (Fig. 12). An initial vesicle bearing a variable number of irregularly distributed outgrowths (Fig. 12.9), which were capable of secondary growth (Fig. 12.11), all suggest that they run active vegetative reproduction. The ability to modify cell shape and division-direction during vegetative growth requires complex cytoskeleton and endomembrane. Functioning cytoskeleton and flexible membranes, which are fundamental conditions to eukaryotes (Cavalier-Smith, 2002), attribute Xiaohongyuia sinica Shi and Feng n. gen. n. sp. to the eukaryotic domain.

\section{Discussion of the microbial community structure}

A silicified microbial community dominated by filaments and coccoids, similar with the new Dahongyu microbiota, was the main community type in the Proterozoic (Schopf, 1968; Schopf and Blacic, 1971; Zhang, 1981, 1985). Although microfossils lack detailed features for systematics because of their simple morphology, their preservation patterns do provide living-habits information. Based on their preservation patterns, endobenthic mat, epibenthic mat, and allochthonous have been recognized.

Endobenthic mat.-Microbial mats that developed inside sediments were interpreted as endobenthic because of their living habit (Noffke, 2010). In this new microbiota, some Siphonophycus filaments were recognized as endobenthic because they possess evidence supporting their development within sediments. In S. thulenema-dominated mats, most filaments are distributed in organic-poor cement (Fig. 6.1, 6.2). Some of these filaments curve along with the outer edge of a pelletoid, suggesting that they grew after pelletoid formation (Fig. 6.1). Siphonophycus robustum and S. septatum also are preserved in organic-poor cements (Fig. 6.3, 6.4), and some are distributed along the outer edge of a pelletoid and show no directional properties (Fig. 6.3). Their position of preservation in the matrix is similar to interstitial filaments of Gunflintia minuta, which were reported from the Gunflint Formation (Lanier, 1989, fig. 5, A-D). These characteristics illustrate that they could have been endobenthic and developed inside sediments. According to
Noffke (2010), endobenthic mats are characteristically found in the upper intertidal zone, which is a nutrition-poor environment. Similar to modern endobenthic mats, growing positions of the endobenthic microfossils of the new microbiota also exhibit characteristics of denutrition because they were preserved in organic-poor sediments.

Epibenthic mat.-Epibenthic microbial mats, which developed on top of sediments, are common microbial mats in modern supratidal environments (Noffke, 2010). Some Siphonophycus filaments exhibited an upward growing habit, which is the same with modern epibenthic microbial mats. In S. typicumdominated mats, filaments intertwined to form some sort of meshwork and exhibited characteristic rhythmic bright and dark layers in their original positions (Fig. 6.5). Bright layers are 200-1000 $\mu \mathrm{m}$ thick and composed of aphanitic chalcedony and microcrystalline quartz. Filaments in bright layers are sparsely preserved in situ and are mostly perpendicular or angled to the lamina. Dark layers are 20-100 $\mu \mathrm{m}$ thick and contain abundant organic material. Filaments in dark layers are rich and tangled, but usually are not very well preserved. These rhythmic characteristics of growth have been interpreted as day-night, tidal or even yearly cycles (Monty, 1976; Zhang and Li, 1984). The characteristic of epitrophy suggests that these were phototrophic organisms and tended to grow on top of the sediments.

Allochthonous individuals.-Isolated individuals in microbial mat biotas used to be designated as allochthonous because they neither participate in the building of microbial mats nor distribute themselves along the bedding plane like mat dwellers (Knoll, 1982). These individuals have also been interpreted as plankton because of their isolated distributional habits (Knoll and Calder, 1983; Knoll et al., 1989, 1991). But, it is not sufficient to identify microfossils as plankton just because they occur as isolated individuals. It also seems impossible to recognize plankton according to their morphological features because they are mostly simple in morphology. Given the above facts, how should we interpret the outstanding flourish of isolated individuals in the new Dahongyu microbiota?

In the new Dahongyu microbiota, about 20\% of the microfossils were preserved as isolated individuals and are characterized by means of their large size. Most of them are larger than $60 \mu \mathrm{m}$ in diameter, and even formed a small frequency distributional peak at about $110 \mu \mathrm{m}$ (Fig. 13). The largest individuals even exceed $400 \mu \mathrm{m}$ in diameter (Fig. 10.1-10.3).

Large microfossils usually are recovered from shales by maceration in Proterozoic strata (Yan, 1982, 1985; Yin, 1985). All their living habit records are lost owing to the maceration process. However, as an in-situ preserved microbiota, the Dahongyu microbiota provides detailed information to help us understand their living habits. Some isolated individuals were broken (Fig. 9.14), which indicates that they were not preserved at their original living position but probably were transported by

Figure 7. Colonially preserved spherical microfossils: (1) Glenobotrydion varioforme: 2007XHYD_47_5 (indicated as 1a) and Eosynechococcus moorei: 2007XHYD_47_5 (indicated as 1b); (2) Glenobotrydion varioforme: 2007XHYD_1_2; (3), Coccostratus dispergens: 2012XHYD_25_15; (4) Myxococcoides sp.: 2012XHYD_1_1; (5) Myxococcoides sp.: 2007XHYD_4_10. All scale bars $=10 \mu \mathrm{m}$. 

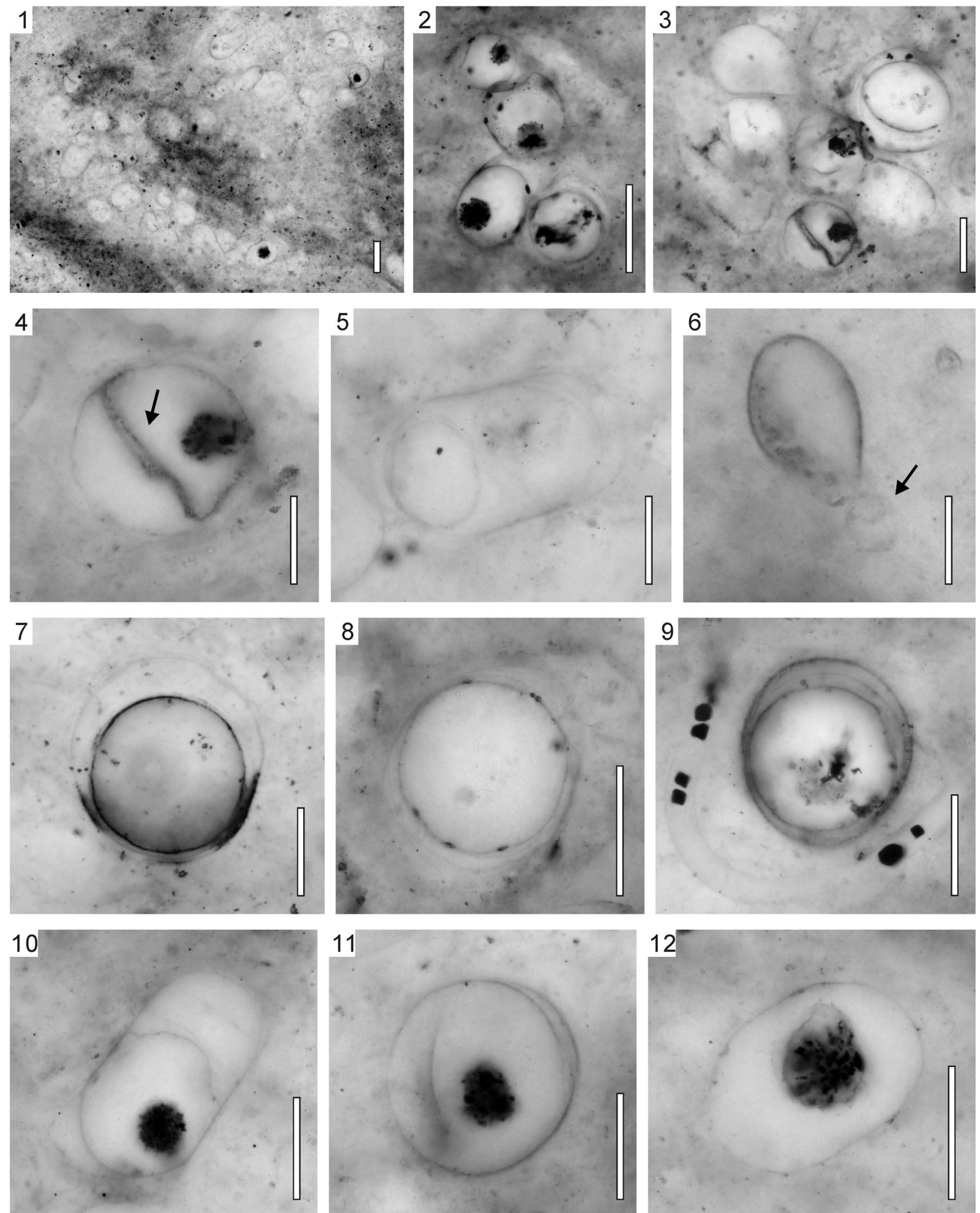

Figure 8. Gloeodiniopsis sp.: (1-3) aggregates of Gloeodiniopsis sp.: 2012XHYD 6 4; (4) splitting cell with a split surface (indicated by black arrow): 2012XHYD_6_4; (5) elongated envelope containing two cells: 2012XHYD_6_4; (6) broken envelope with a small cell: 2012XHYD_6_4; (7-9) cells with two or three layers of envelopes: 2012XHYD_6_4; (10-12) cells with dark inclusions: 2012XHYD_6_4. All scale bars $=25 \mu \mathrm{m}$. 
water flow. According to the sequence stratigraphic information and stromatolites, the fossiliferous beds are located in the upper part of a transgressive sequence. They were deposited in an intertidal environment and are dominated by shallow-water carbonates. Fossil-bearing rocks containing a large amount of broken fragments of microbial mats, pelletoids, and concentrical ooids indicated a turbulent water environment, which allowed plankton habitation. Combined with environmental and taphonomic information, these broken isolated individuals could be considered as potential plankton.

In summary, this new microbiota, which contains endobenthic, epibenthic, and allochthonous elements, shows a vertical distributional view of an intertidal microbiota in the transitional time from Paleoproterozoic to Mesoproterozoic.

\section{Regional disparity of the Dahongyu microbiota}

All of the previously reported microfossils from the Dahongyu Formation were concentrated at the Pangjiapu section, which is located in the west of the Yanshan basin and is $185 \mathrm{~km}$ away from the Jixian section. The Dahongyu microbiotas from two localities (the Pangjiapu and the Jixian sections) both have high abundance, but also possess some obvious differences. To date, several studies have been conducted in the Pangjiapu section, with only nine taxa being recovered: Gunflintia, Huroniospora, Gloeotheceopsis aggregate, Gloeodiniopsis mattiformatum, Glenobotridion granulosum, Siphonophycus inornatum, Eohyella campbellii, Coniunctiophycus conglobatum, and Sphaerophycus sp. (Zhang, 1984, 1988; Zhang and Golubic, 1987; Zhang et al., 1995). These nine taxa of the Pangjiapu section are colonial microfossils with simple morphology.

Compared with the Pangjiapu section, the newly studied Jixian section contains more diversified microfossils. Besides colonial microfossils, the Jixian section also contains abundant allochthonous microfossils, which were not present in the Pangjiapu section. As in the Pangjiapu section, in many silicified microbial mat biotas in the Paleoproterozoic and Mesoproterozoic (e.g., microbiotas from the Gaoyuzhuang Formation, Wumishan Formation, Salkhan limestone, Yusmastakhan Formation, and Dismal Lakes Group), isolated individuals usually were rare elements and only account for 2\% of microbiota (Horodyski and Donaldson, 1980; Zhang, 1981, 1985; Sergeev et al., 1995; Sharma, 2006). In the new Dahongyu microbiota, the content of large isolated individuals is up to $20 \%$. The high content of isolated individuals made the Jixian section standout compared to other silicified microbiotas in Paleoproterozoic and Mesoproterozoic strata.

Gunflintia and Huroniospora have been reported from the Dahongyu Formation of the Pangjiapu section (Zhang, 1984), but no typical Gunflint elements have been discovered in the same formation of the Jixian section. Only some S. thulenema share a similar preservable pattern with the interstitial filaments, which have been assigned to Gunflintia minuta from the Gunflint Formation (Lanier, 1989). Gunflint microbiotas are considered a result of a special environment (Zhang, 1984). They are comprised of special components restricted to an exclusive time interval (2.1-1.7 Ga) and mostly associated with banded iron formations (Licari and Cloud, 1968; Knoll and Barghoorn, 1976; Awramik and Barghoorn, 1977; Tobin, 1990).
Disparity of the sedimentary environment could be the cause of biological disparity. By comparing both microbiotas of the Jixian section and the Pangjiapu section, it could be inferred that there was significant environmental disparity between the two localities. The Pangjiapu section, which is $185 \mathrm{~km}$ from the Jixian section, is located in the same Yanshan basin with the Jixian section. The whole Dahongyu Formation of the Pangjiapu section, which contains well-preserved microfossils, is dominated by carbonates like the third member of the Dahongyu Formation in the Jixian section. In both localities, microfossils are recovered from cherts and silicified carbonates. Besides these similarities, absence of volcanic materials and detrital rocks in the Pangjiapu section is the main difference between the two localities. As mentioned above, widespread and long-standing volcanic activities occurred and induced significant regional disparity of volcanic sediments and terrestrial inputs during deposition of the Dahongyu Formation (Ren, 1987). Compared to the Pangjiapu section, the Jixian section is closer to the provenances and more nutrition provided by volcanic materials could have influenced the microbiota to flourish. Although there are numerous environmental possibilities that could influence size and diversity in ancient basins, nutrition is an important factor that could limit or promote the growth of microfossils in a carbonate tidal-flat environment.

\section{Comparison with the Chuanlinggou microbiota}

The ca. 1650 Ma Chuanlinggou microbiota, recovered from the underlying Changcheng Group, is well known for bearing the earliest ornamented acritarch Valeria lophostriata (Yan and Liu, 1993; Peng et al., 2009). The Chuanlinggou microbiota was recovered from shales, which were considered to have been deposited in a barrier-island lagoon with hydrostatic environment and sufficient terrestrial inputs (Xu et al., 2002b). Abundant microfossils have been reported from the Chuanlinggou Formation (Yan, 1982, 1985, 1991; Yan and Liu, 1993; Sun, 2006), and most of these microfossils are smooth-surfaced (Peng et al., 2007; Peng et al., 2009). The Dahongyu microbiota was recovered from cherts and silicified carbonates, which are chemical sediments representing littoral-neritic sea environments. Microbiotas from totally different environments, such as the Chuanlinggou and Dahongyu microbiotas, usually are composed of different microfossils. However, the presence of plentiful isolated individuals made the Dahongyu microbiota comparable with the Chuanlinggou microbiota.

These two microbiotas share main microfossil components: (1) the Chuanlinggou microbiota and the Dahongyu microbiota are both dominated by filaments and small coccoids (Xing and Liu, 1973; Yan and Liu, 1993); (2) large spherical microfossils are abundant elements in both microbiotas (Yan and Liu, 1993); and (3) large fusiform (or ovoidal-shaped) microfossils, which are half roll-ups of a regular ruptured envelope, are frequent microfossils in the Chuanlinggou Formation (Peng et al., 2007; Peng et al., 2009). The same fusiform envelopes are also common microfossils in the Dahongyu microbiota (Fig 11.6-11.7).

In addition to similarities, rare microfossils differ between these two microbiotas. A new type of small fusiform microfossil 

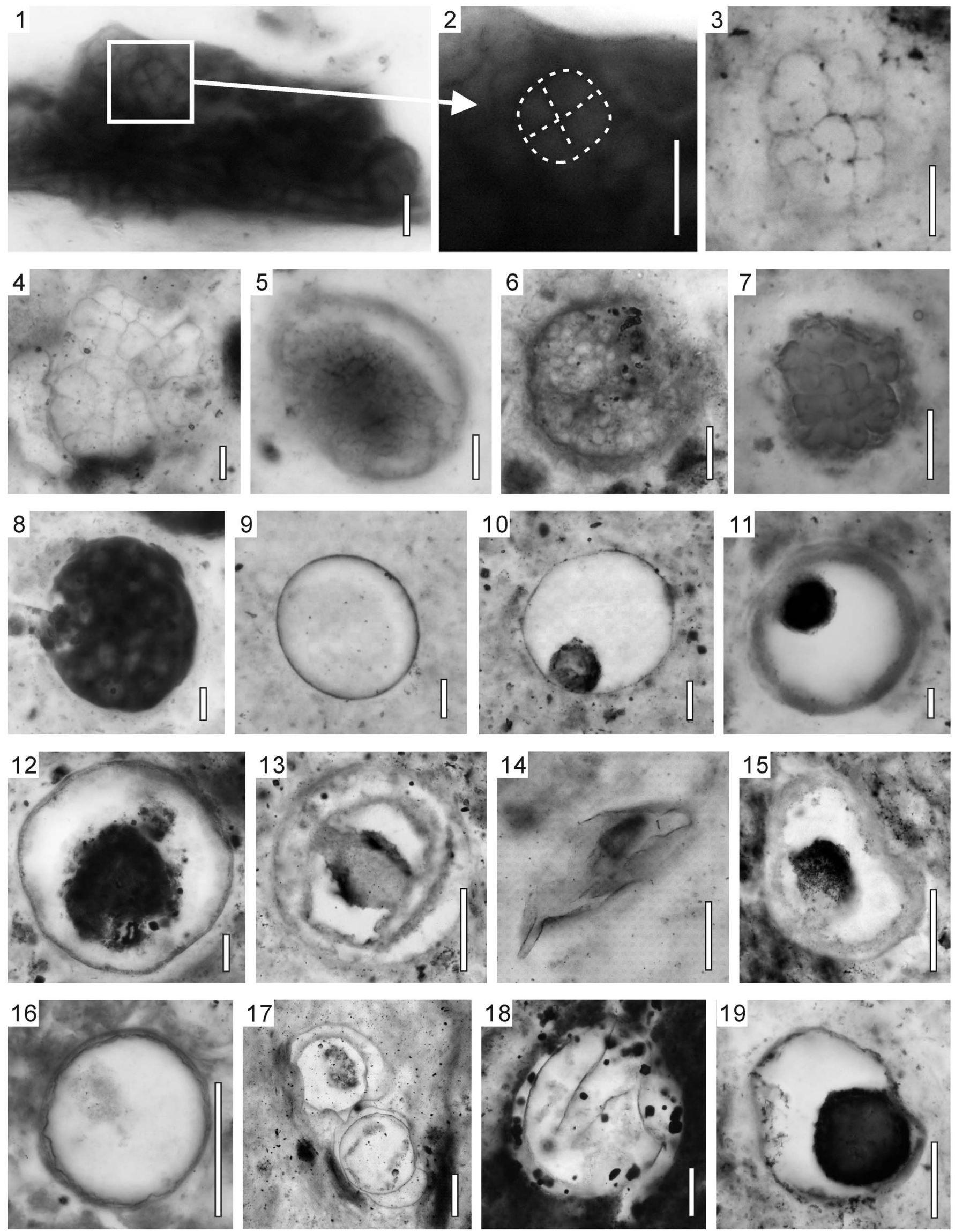

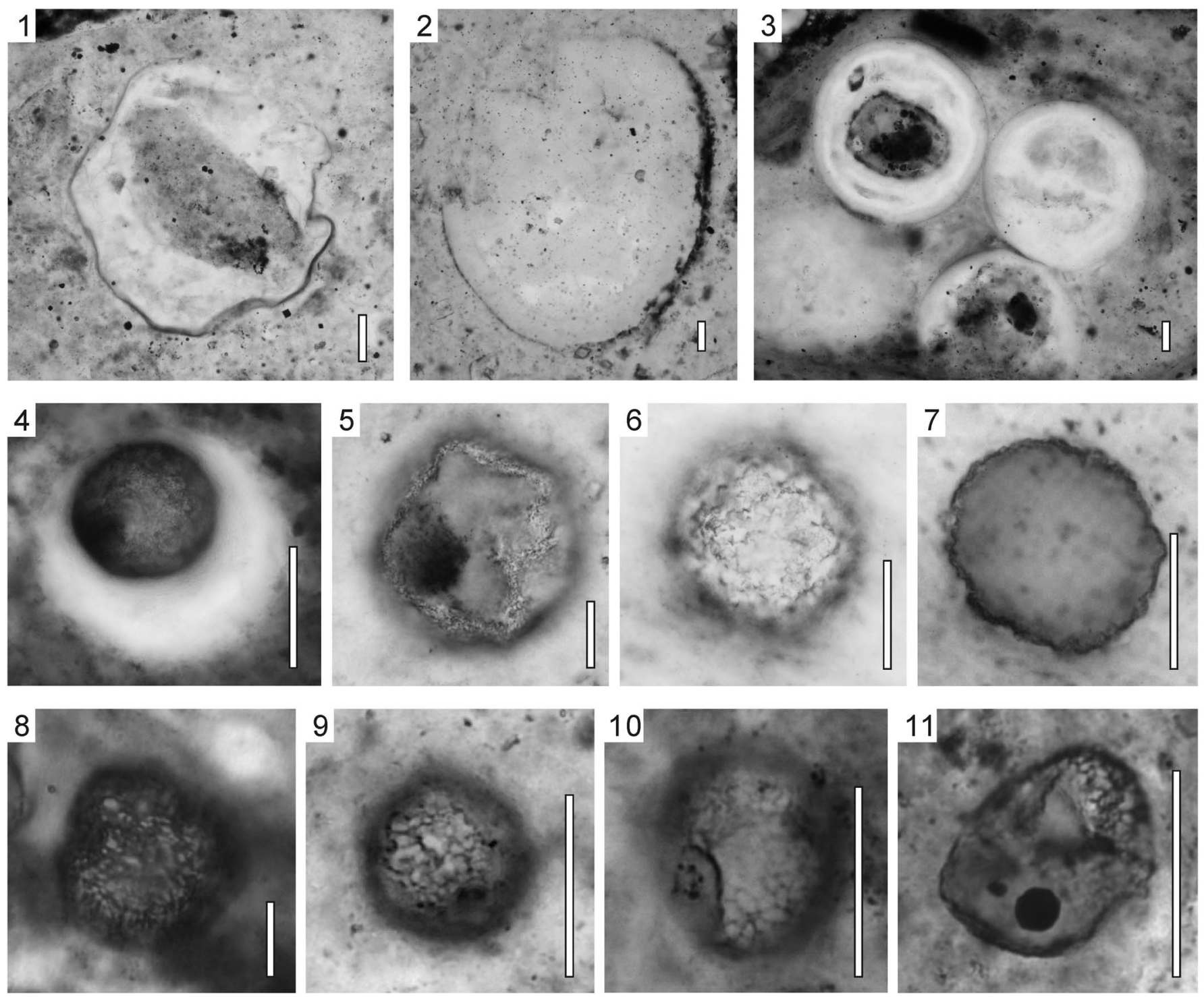

Figure 10. Spherical microfossils: (1-5) Leiosphaeridia sp.: (1) 2007XHYD_4_19; (2) 2007XHYD_47_5; (3) 2007XHYD_3_5; (4) 2007XHYD_3_5; (5) 2012XHYD_21_8; (6-9) Asperatopsophosphaera umishanensis: (6) 2007XHYD_2_1; (7) 2007XHYD_2_1; (8) 2007XHYD_4_10a; (9) 2007XHYD_4_17; (10, 11) Dictyosphaera macroreticulta: (10) 2012XHYD_21_17; (11) 2012XHYD_16_14. Scale bars are (1-3) $50 \mu \mathrm{m}$ and $(\mathbf{4 - 1 8}) 40 \mu \mathrm{m}$.

(Leioarachnitum sp., Fig. 11.1-11.5) has been recovered from the Dahongyu Formation. Leioarachnitum sp. is a complete envelope with or without a longitudinal rupture, which is different from the roll-ups of half envelopes from the Chuanlinggou Formation. According to microfossil records, small fusiform microfossils are widely distributed in the overlying Jixian Group (Cao, 2005; Shi et al., 2014). In addition, the ornamented acritarch Valeria lophostriata, which is present in the Chuanlinggou Formation, is absent in the Dahongyu microbiota. However, several microfossils from the Dahongyu microbiota exhibit ornament (e.g., granular, reticulate, and spiny). These ornaments are homogenetic and regular in morphology, which differ from the cracks and foldings resulting from biological decay or diagenesis. Finally, some microfossils with complex morphology, such as the Unnamed Form 1, Unnamed Form 6, and the Xiaohongyuia sinica Shi and Feng n. gen. n. sp., in the Dahongyu microbiota, are new findings that the Chuanlinggou Formation does not contain. Among them, the ability of modification in cell shape and division-direction during vegetative growth made the Xiaohongyuia sinica Shi and Feng n. gen. n. sp. different from other microbial fossils.

Figure 9. Spherical microfossils: (1, 2) Tetraphycus gregalis: 2007XHYD_3_11; (3, 4) Coniunctiophycus majorinum: (3) 2012XHYD_16_45; (4) 2012XHUD_25_13; (5-8) Clonophycus sp.: (5) 2012XHYD_25_1a; (6) 2012XHYD_16_4; (7) 2012XHYD_1_16; (8) 2012XHYD_25_11; (9) Myxococcoides grandis: 2012XHYD_6_11; (10-18) Leiosphaeridia sp.: (10) 2012XHYD_14_18; (11) 2012XHYD_25_14; (12) 2007XHYD_4_11; (13) 2012XHYD_25_13; (14) 2012XHYD_4_1; (15) 2012XHYD_20_16; (16) 2012XHYD_20_18; (17) 2012XHYD_7_25; (18) 2012XHYD_16_14; (19) Pterospermopsimorpha sp.: 2007XHYD_3_18. Scale bars are (1-11) $10 \mu \mathrm{m}$ and (12-19) $50 \mu \mathrm{m}$. 

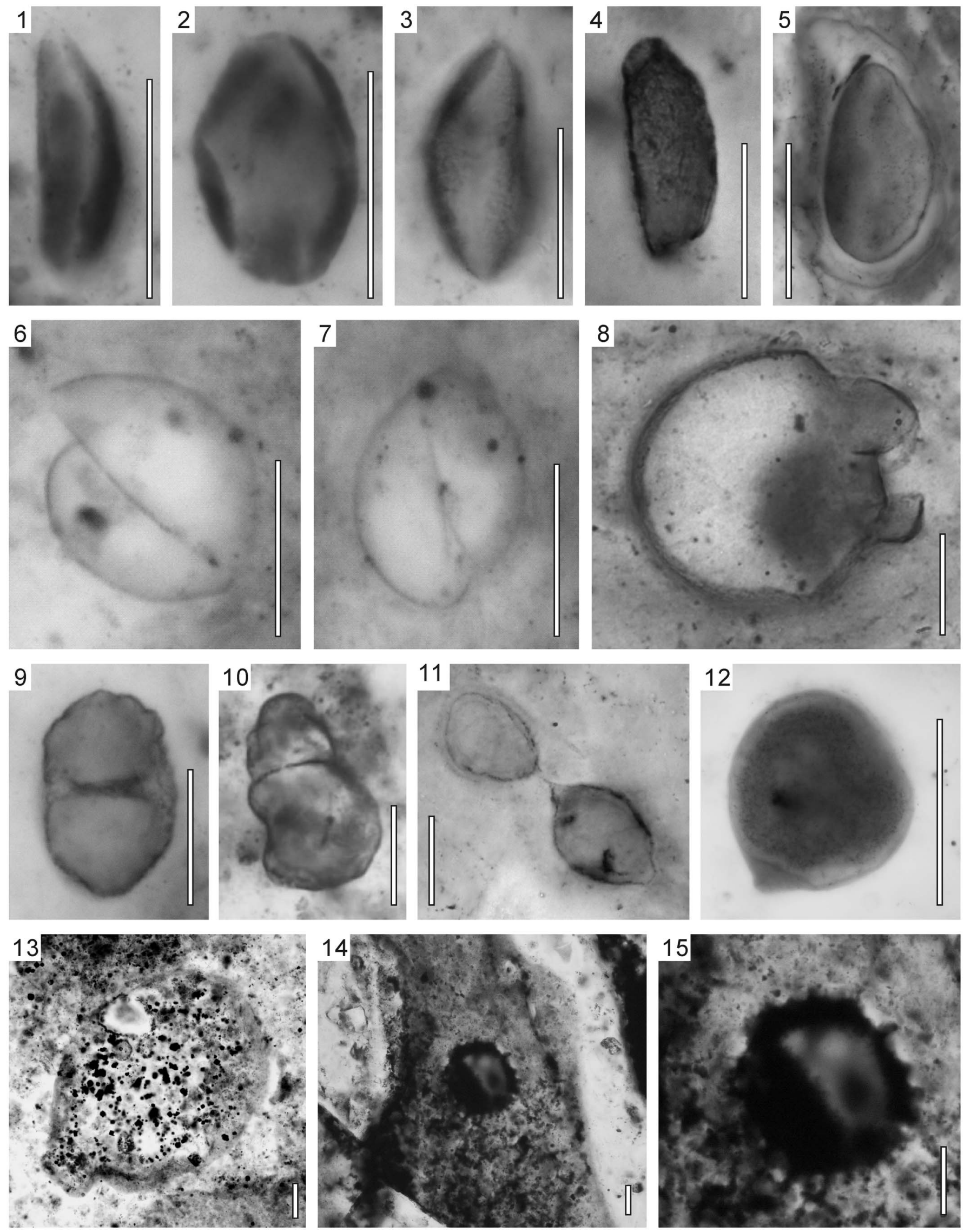

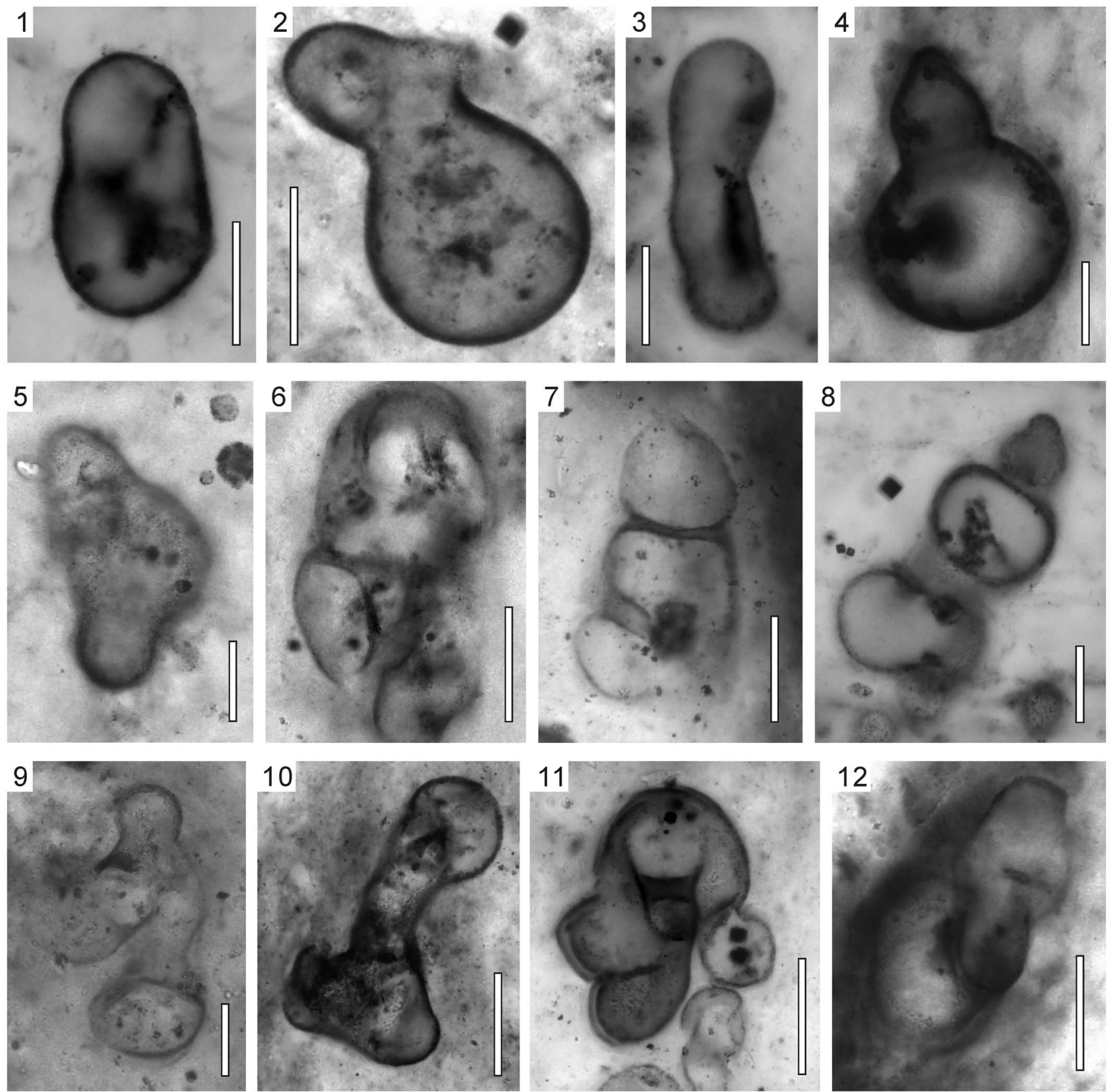

Figure 12. Xiaohongyuia sinica Shi and Feng n. gen. n. sp.: (1) 2007XHYD_4_7; (2) 2007XHYD_4_10; (3) 2007XHYD_4_8; (4) 2007XHYD_4_21; (5) 2007XHYD_4_23; (6) 2007XHYD_4_14a; (7) 2007XHYD_4_14; (8) 2007XHYD_4_21; (9) holotype 2007XHYD_4_14; (10) 2007XHYD_4_17; (11) 2007XHYD_4_17; (12) 2007XHYD_4_10. All scale bars $=30 \mu \mathrm{m}$.

\section{Significance of the new Dahongyu microbiota}

On the basis of expanded documentation of complex fossils, the transitional time from Paleoproterozoic to Mesoproterozoic has already been proven as a significant era for eukaryotic evolution.
Previous research suggested that main clades of green algae separated in the late Paleoproterozoic and early Mesoproterozoic (Teyssèdre, 2006; Moczydłowska et al., 2011). During this era, several eukaryote-bearing strata were studied, such as the 1650 Ma McArthur Group from Australia, the 1500 Ma Kotuikan

Figure 11. Allochthonous forms: (1-5) Leioarachnitum sp.: (1) 2012XHYD_3_16; (2) 2012XHYD_3_14; (3) 2007XHYD_3_11; (4) 2012XHYD_14_20; (5) 2012XHYD_25_14; (6, 7) Leiosphaeridia minutissima: 2012XHYD_7_25; (8) Unnamed Form 1 spherical microfossil with broken, neck-like extension: 2007XHYD_2_3a; (9) Unnamed Form 2 rough-surfaced dyad spherical microfossil: 2007XHYD_2_1; (10) Unnamed Form 3 inequable dyad spherical microfossils: 2012XHYD_14_1a; (11) Unnamed Form 4 dividing cells: 2007XHYD_2_1; (12) Unnamed Form 5 spherical microfossil with a spine-like structure: 2007XHYD_3_22; (13) Unnamed Form 6 vase-shaped microfossil?: 2012XHYD_6_4; (14, 15) Unnamed Form 7, probable acanthomorphic acritarch: 2007XHYD_4_24. All scale bars $=30 \mu \mathrm{m}$. 


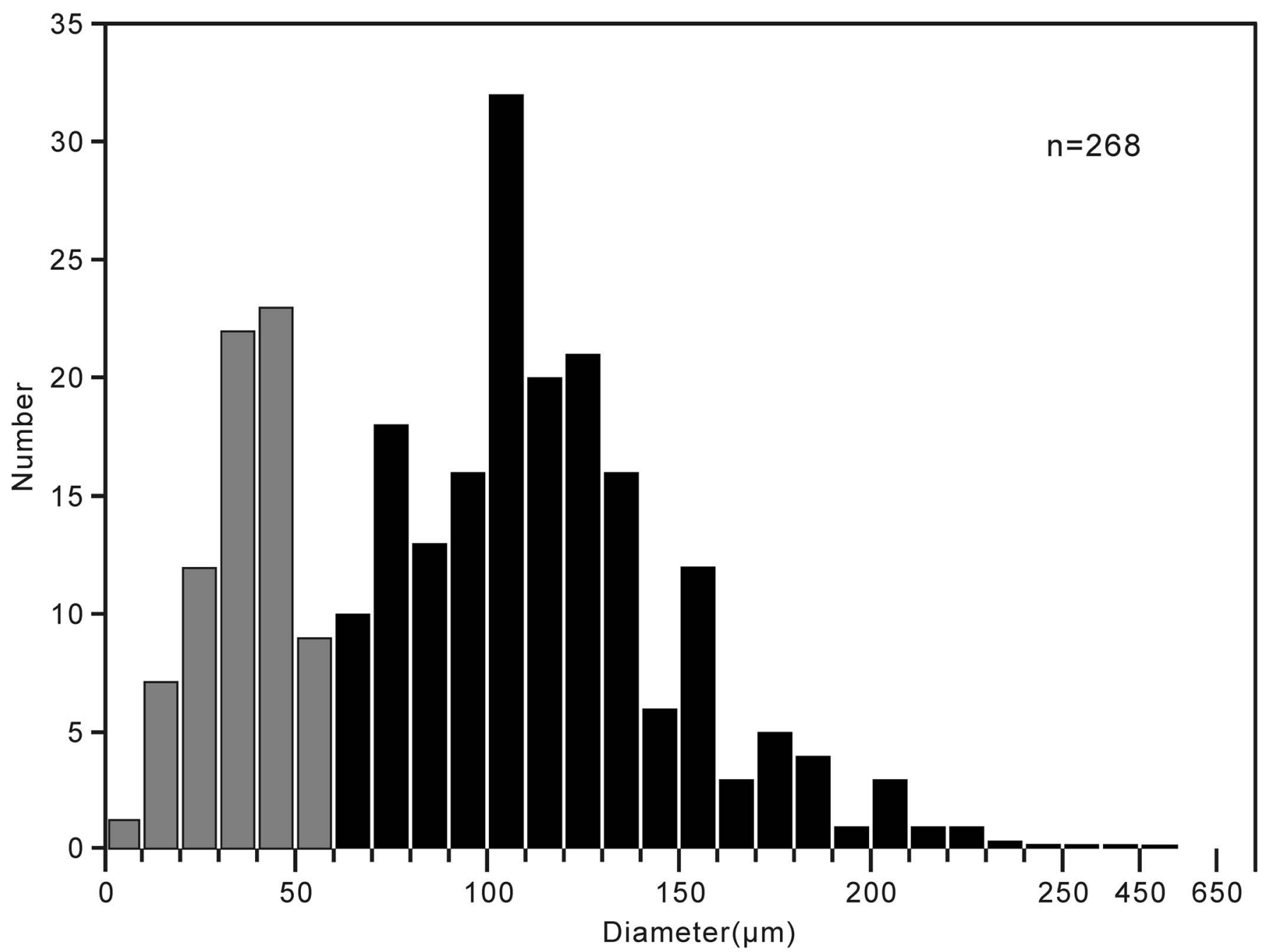

Figure 13. Diameter-frequency distributions of isolated individuals of coccoidal microfossils. Gray bars indicate spherical microfossils $<60 \mu \mathrm{m}$ in diameter; black bars indicate spherical microfossils $>60 \mu \mathrm{m}$ in diameter.

Formation from Siberia, the 1450 Ma Roper Group from Australia, the $>1400$ Ma Ruyang Group from North China, and the $1400 \mathrm{Ma}$ Greyson Formation from United States (Xiao et al., 1997; Javaux et al., 2001; Javaux and Marshal, 2006; Peng et al., 2009; Vorob'eva et al., 2015; Adam et al., 2016). These strata (the Kotuikan Formation from Siberia is an exception) are comparable with each other for bearing the same microfossils. The underlying Changcheng Group of the Dahongyu Formation in the Jixian section could also be considered comparable with the McArthur Group because they share Valeria lophostriata, similar age, and lithology (Yan and Liu, 1993; Javaux and Marshal, 2006).

However, the Dahongyu microbiota, together with subsequent microbiotas of the Jixian Group in the whole Yanshan Basin, exhibit totally different microbiotic components. Although, tens of thousands of microfossils have been reported from the Proterozoic Yanshan Basin (Sun, 2006; Shi et al., 2014), microfossils with complex morphology or ornament are still rare or debatable. Complex eukaryotes, such as Tappania, Satka and Shuiyousphaeridium, which are abundant microfossils in several locations (Xiao et al., 1997; Javaux et al., 2001;
Javaux and Marshal, 2006; Peng et al., 2009; Vorob'eva et al., 2015; Adam et al., 2016), were absent in the Dahongyu Formation and any strata in the entire Yanshan Basin. Even Valeria lophostriata, which emerged in the underlying Changcheng Group, is absent in the subsequent strata. Although some allochthonous forms from the Dahongyu microbiota possess ornaments or odd morphology, there is a long path to follow before their eukaryotic nature can be proven because they are either too simple or too rare.

In the Proterozoic Yanshan Basin, carbonates initially emerged in the upper part of the Changcheng Group and dominated the sediments in the Jixian Group. Microbiotas, such as the Dahongyu microbiota, became the dominant or only type of microbiota in these carbonate-dominated strata of the Yanshan Basin (Shi et al., 2014; Fig. 5). However, based the record of several potential eukaryotes in the newly studied Dahongyu microbiota and Valeria lophostriata in the underlying Changcheng Group (Peng et al., 2009), it could be inferred that eukaryotic life was already well established in the transitional time and had undergone a moderate diversification. Among reported potential eukaryotes in the Yanshan Basin, the 
small fusiform microfossil Leioarachnitum sp. (Fig. 11.1-11.5), which is abundant in the Dahongyu microbiota, is a unique microfossil in the Yanshan Basin. It occurs in the upper part of the Changcheng Group along with the carbonate-dominated strata and is distributed in several strata of the Jixian Group (Cao, 2005; Shi et al., 2014). It is worth mentioning that a well-preserved eukaryote-bearing microbiota reported from the 1500 Ma Kotuikan Formation in Siberia is not comparable with the Roper Group and the Ruyang Group. Based on these differences, it is obvious that large regional disparities of microbiotas existed between continents. These could be caused by regional disparity of depositional environment, habitat, or other conditions. Causal factors behind these disparities need further study.

\section{Conclusions}

The new Dahongyu microbiota is dominated by cyanobacteria filaments and coccoids, including endobenthic, epibenthic, and allochthonous forms, which illustrated well a vertical distributional profile of an intertidal microbiota from the transitional Paleoproterozoic and Mesoproterozoic time.

High content and large size of allochthonous forms are the defining characteristics that make the Dahongyu microbiota extraordinarily different from other microbial mat biotas recovered from cherts of this contemporary time. Most microfossils of the new Dahongyu microbiota are smooth-surfaced and morphologically simple, yet a few possess ornaments or odd morphologies that suggest their potential eukaryotic nature.

During deposition of the Dahongyu Formation, significant regional disparity of microbiotas existed within the Yanshan Basin. The newly studied Dahongyu microbiota has certain distinctions, but is mostly similar to the microbiota from the underlying Changcheng Group. Absence of typical eukaryotes from the coeval time and the presence of unique elements (especially small fusiform microfossils) make the Dahongyu microbiota and subsequent microbiotas in the Jixian Group distinct from coeval eukaryote-bearing microbiotas.

\section{Systematic paleontology}

Kingdom Eubacteria Woese and Fox, 1977

Phylum Cyanobacteria Stanier et al., 1978

Class Hormogoneae Thuret, 1875

Order Oscillatoriales Elenkin, 1949

Family Oscillatoriaceae (Gray) Kirchner, 1900

Genus Oscillatoriopsis Schopf, 1968, emend. Mendelson and

Schopf, 1982, emend. Butterfield et al., 1994

Type species.—Oscillatoriopsis obtusa Schopf, 1968.

Remarks.-More than 100 "species" of Oscillatoriopsis have been reported, but it is problematic to distinguish or compare them. Having undergone several amendments, width was chosen as the species-level principal criterion (Butterfield et al., 1994). Although morphological species based on width have limited information regarding their biological nature, it is efficient to distinguish Oscillatoriopsis species using this diagnosis.
According to the statistics of width, three morphological species from the Dahongyu Formation are present: O. obtusa (>3.0-8.0 $\mu \mathrm{m}$ in width), O. amadeus $(>8.0-14.0 \mu \mathrm{m}$ in width), and $O$. longa ( $>14.0-25.0 \mu \mathrm{m}$ in width). In addition to this, some Oscillatoriopsis trichomes, which are more than $25 \mu \mathrm{m}$ in width, are placed under $O$. princeps formally $(>25-50 \mu \mathrm{m})$.

Oscillatoriopsis princeps Zhang and Yan, 1984, emend. Shi and Feng, herein

Figure 3.5, 3.6

1984 Oscillatoriopsis princeps Zhang and Yan, p. 198, pl. 1, fig. 6.

Holotype.-Specimen illustrated by Zhang and Yan (1984, pl. 1, fig. 6.).

Description.-Multicellular, unbranched trichome without sheath. Trichomes are $25-35.8 \mu \mathrm{m}$ in diameter $($ mean $=29.5 \mu \mathrm{m}$; $\mathrm{N}=30$ ). Single cells are $5.1-10.5 \mu \mathrm{m}$ in length and their ratio of length to width is $0.2-0.3$. Septa are not constricted.

Remarks.-Oscillatoriopsis princeps was first named for its extremely large diameter (19-37.5 $\mu \mathrm{m}$ in diameter) (Zhang and Yan, 1984). It used to be assigned to $O$. longa (Butterfield et al., 1994). Considering that the holotype of $O$. princeps is $37.5 \mu \mathrm{m}$ in diameter, here it is formally emended in the range of $25-50 \mu \mathrm{m}$ in diameter and all large Oscillatoriopsis filaments from the Dahongyu Formation (25-35.8 $\mu \mathrm{m}$ in diameter) were assigned into $O$. princeps.

Class Coccogoneae Thuret, 1875

Order Chroococcales Wettstein, 1924

Family Chroococcaceae Nägeli, 1849

Genus Gloeodiniopsis Schopf, 1968, emend. Knoll and Golubic, 1979

Type species.-Gloeodiniopsis lamellosa Schopf, 1968, Bitter Spring Formation, Australia.

Gloeodiniopsis sp. indet. Figure 8.1-8.12

Description.-Colonially preserved spherical microfossils with thin, transparent, smooth-surfaced flexible wall. Single cells are $19-68 \mu \mathrm{m}$ in diameter $(\mathrm{N}=100)$. Cell walls are occasionally multi-layered. Figure 8.3 displays their reproduction procedure of straight splitting. Envelope containing two cells (Fig. 8.4, 8.5) and broken envelope with a small cell (Fig. 8.6) shows the subsequent procedures of splitting, during which the daughter cells slipped out of the common envelope. Tens to hundreds of cells are loosely distributed into colonies.

Discussion.-These microfossils differ from Leptoteichos golubicii and Myxococcoides grandis because some have multilayered walls. They differ from G. lamellosa because their outer sheaths are thin and ghost-like.

Incertae sedis

Genus Clonophycus Oehler,1977, emend. Oehler,1978 
Type species.—Clonophycus elegans Oehler, 1977.

Clonophycus sp. indet.

Figure 9.5-9.8

Description.-Spherical coenobium with or without a common envelope. Coenobiums range from $30-57.5 \mu \mathrm{m}$ in diameter $(\mathrm{N}=12)$ and are composed of tens to hundreds of spherical cell units. Cell units $2.5-12.5 \mu \mathrm{m}$ in diameter.

Remarks.-These specimens are morphologically comparable to Clonophycus, which has been reported from the Proterozoic Balbirini Dolomite, Australia (Oehler, 1978).

\section{Genus Xiaohongyuia new genus Shi and Feng}

Type species.-Xiaohongyuia sinica new genus new species Shi and Feng.

Diagnosis.-An initial vesicle bearing a variable number of irregularly distributed outgrowths. It is characterized for its variable morphology, including but not limited to spherical, binary, lageniform, calabash and chain-like. Irregular-shaped individuals are composed of incomplete spherical parts in various directions.

Etymology.-With reference to their occurrence in Xiaohongyu Valley.

Occurrence.-Fossiliferous bed located $\sim 15 \mathrm{~m}$ from the top of the third member of the Dahongyu Formation, in the Xiaohongyu Valley in Jixian area, Tianjin, north China.

Remarks.-Ordinary cells of Xiaohongyuia Shi and Feng n. gen. are mostly spherical. Irregular-shaped individuals are a minority and are composed of incomplete spherical parts in different directions. Cross-walls between every spherical part have been observed in many irregular-shaped specimens. These cross-walls partition the whole organism into two unequal vesicles; or into gourd-, lageniform-, dumbbell-, calabash- and chain-shaped organisms. According to their variable morphology, $X$. sinica Shi and Feng n. sp. could undergo active vegetative reproduction. They have a tendency to develop outgrowths from the initial vesicle, sometimes to the extent of forming secondary vesicles.

\section{Xiaohongyuia sinica new species Shi and Feng}

Figure 12

Holotype.-The microfossil illustrated in Figure 12.9 is hereby designated as holotype for this species. The holotype specimen is found in Slide 2012JXD4, Dahongyu Formation, Jixian section, Tianjin, China.

Diagnosis.-Outgrowths grown in two perpendicular directions.

Description.-Irregular-shaped organisms. Outgrowths grew in two perpendicular directions. They are, but not limited to, binary, lageniform, calabash, and chain-like morphologies. Single cells are in the range $15.5-45 \mu \mathrm{m}$ in diameter (mean = $29 \mu \mathrm{m} ; \mathrm{N}=46$ ).

Etymology.-With reference to their occurrence in China.

Group Acritarcha Evitt, 1963

Genus Pterospermopsimorpha (Timofeev,1966), emend. Mikhailova and Jankauskas in Jankauskas et al., 1989

Type species.-Pterospermopsimorpha pileiformis Timofeev, 1966.

\section{Pterospermopsimorpha sp. indet.}

Figure 9.14

Description.-Solitary spherical microfossils with a large, spherical dark inclusion. Wall is thin and transparent. Cells are $38.5-126.5 \mu \mathrm{m}$ in diameter $($ mean $=72.2 \mu \mathrm{m}, \mathrm{n}=15)$. Inclusions are $23.8-97.2 \mu \mathrm{m}$ in diameter (mean $=47.5 \mu \mathrm{m}, \mathrm{N}=15$ ).

Remarks. - We agree with Jankauskas et al. (1989) and include all smooth-surfaced spheres with large spherical inclusions (usually bigger than two-thirds cell diameter) from the new microbiota into Pterospermopsimorpha. According to microfossil records, Pterospermopsimorpha emerged as early as late Paleoproterozoic (Yan, 1985), but were more abundant in the late Proterozoic.

\section{Genus Dictyosphaera Xing and Liu, 1973}

Type species.-Dictyosphaera macroreticulta Xing and Liu, 1973.

\section{Dictyosphaera macroreticulata Xing and Liu, 1973} Figure 10.10, 10.11

1973 Dictyosphaera macroreticulata Xing and Liu, p. 22, pl. 1, figs. 16, 17.

2015 Dictyosphaera macroreticulata Xing and Liu; Agić et al., p. 32, fig. 2.1-2.9.

For additional synonymy see Agić et al., 2015.

Holotype.-Specimen illustrated in pl. 1, fig. 16 (Xing and Liu, 1973).

Description.-Spherical cells with reticulate sculptures on their surface. Cells are $40.5-49.5 \mu \mathrm{m}$ in diameter $($ mean $=45 \mu \mathrm{m}$; $\mathrm{N}=2$ ). Cell wall is single-layered, thick, and translucent.

Remarks.-Dictyosphaera was first described from the Chuanlinggou Formation of the Jixian section (Xing and Liu, 1973), and subsequently reported from several localities in Mesoproterozoic strata in North China ( $\mathrm{Hu}$ and Fu, 1982; Yan and Liu,1993; Xiao et al., 1997; Li et al., 2012; Agić et al., 2015). The new specimens are similar to the "Dictyosphaera sinica" reported from the Chuanglinggou Formation, Jixian section (Xing and Liu, 1973; Fig. 1.18, 1.19). Their reticulate sculptures 
are both very small and simple. Recently, Agić et al. (2015) emended Dictyosphaera as a monospecific genus, so we assign the new specimens to D. macroreticulata.

Genus Asperatopsophosphaera Shepeleva, 1963

Type species.—Asperatopsophosphaera bavlensis Shepeleva, 1963.

Asperatopsophosphaera umishanensis Xingand Liu, 1973

Figure 10.6-10.9

1973 Asperatopsophosphaera umishanensis Xing and Liu, p. 21, pl. 2, figs. 2, 3 .

Holotype.-Specimen 4-7/1858(3), illustrated by Xing and Liu (1973, pl. 2, fig. 2).

Description.-Spherical cells with a granular surface and a dense wall. Cells are $26.7-55.4 \mu \mathrm{m}$ in diameter (mean $=35.5$ $\mu \mathrm{m} ; \mathrm{N}=15$ ). Some possess uneven outlines (Fig. 10.7).

Remarks.-Granular ornamentation on microfossils from the late Paleoproterozoic were considered taphonomic signatures (Peng et al., 2007; Peng et al., 2009). On this basis, the existence of the taxon A. umishanensis became debatable. According to some previously reported materials and new specimens in the Dahongyu Formation, granular-surfaced and dense-walled A. umishanensis emerged from the Dahongyu Formation, and became more abundant upwards in the Jixian Group (Xing and Liu, 1973; Sun, 2006). Granular ornamentation on their surface is clear and uniform, which is different from cracks and foldings resulting from biological decay or diagenesis (Zhang and Liu, 1991). For these reasons, we assign these specimens to A. umishanensis.

Genus Leioarachnitum Andreeva et al., 1966

Type species.—Leioarachnitum vittatum Andreeva et al., 1966.

Leioarachnitum sp. indet. Figure 11.1-11.5

Description.-Solitary and fusiform units with a medial split that is parallel to the long axis direction. Walls are dense and opaque. Both ends taper and are rounded or blunt. Cells are 8-53 $\mu \mathrm{m}$ long (mean $=31 \mu \mathrm{m} ; \mathrm{N}=23$ ) and $4-27 \mu \mathrm{m}$ wide (mean $=15 \mu \mathrm{m} ; \mathrm{N}=23$ ). Length is $2-3$ times greater than the width. Some of their medial splits are open, but others are not.

Remarks.—Leioarachnitum sp. has been reported as "boatshaped microfossils" from cherts of the Gaoyuzhuang Formation, Jixian section (Cao, 2005, p. 547). The emergence of some specimens of Leioarachnitum sp. without rupture (Fig. 11.4, $11.5)$ in the new microbiota may demonstrate their features before excystment. Therefore, Leioarachnitum sp. is probably a different microorganism from those roll-ups of half envelope in Chuanlinggou Formation (Peng et al., 2009). Medial splitbearing "Schizofusa" from the Changcheng Group has the same fusiform characteristic, but also reveals that they are rolled up "half envelopes" (Yan, 1982, 1985; Yan and Liu, 1993; Peng et al., 2009). Unlike the "Schizofusa" specimens, Leioarachnitum sp. from the Dahongyu Formation is a whole envelope, which is in accord with the original description of "Schizofusa" (Yan, 1982). Their medial splits have been interpreted as excystment structures of eukaryotic algae (Lamb et al., 2009), which seems reasonable for the Leioarachnitum sp. described here.

\section{Unnamed Form 1 \\ Figure 11.8}

Description.-Spherical cell with a broken, neck-like extension. Cells sizes $76-80 \mu \mathrm{m}$ in diameter $(\mathrm{N}=3)$. Their walls are transparent and smooth-surfaced.

Discussion.-Extensions with different morphology have been observed on Tappania, which is the characteristic microfossil in coeval strata. Detailed morphology of these specimens, especially the neck-like extensions, is needed before comparing to Tappania.

\section{Unnamed Form 2 \\ Figure 11.9}

Description.-Cells are spheroidal, occurring in pairs within a common organic wall. The outer wall is coarsely granulated. The cell pair is $25 \mu \mathrm{m}$ in width and $41 \mu \mathrm{m}$ in length $(\mathrm{N}=1)$.

Discussion.-Cell pairs from the Bitter Spring Formation have been named Eozygion and then interpreted as a synonym of the Gloeodiniopsis (Schopf and Blacic, 1971; Knoll and Golubic, 1979). The Dahongyu specimens are different from the Bitter Spring specimens because of their granulated surface.

\section{Unnamed Form 3 Figure 11.10}

Description.-Cells are spheroidal, occurring in pairs without a common envelope. The larger cell of the pair is $33 \mu \mathrm{m}$ in length and $30 \mu \mathrm{m}$ in width. The smaller cell is $17 \mu \mathrm{m}$ in length and $22 \mu \mathrm{m}$ in width $(\mathrm{N}=1)$. The outer surface is smooth.

\section{Unnamed Form 4 \\ Figure 11.11}

Description.-Dividing cells without any common envelope. Cells are lentiform in morphology, and are connected to each other by their elongated wall in the direction of the long axis. Cells have smooth and transparent outer surfaces. Cells vary from $39.5-49 \mu \mathrm{m}$ in length and range from 29 to $32 \mu \mathrm{m}$ in width $(\mathrm{N}=1)$. Two cells are conjoined by their elongated outer wall.

\section{Unnamed Form 5 Figure 11.12}

Description.-Solitary spherical microfossils with a single spine-like structure on its surface. Cells vary in diameter from $30-34 \mu \mathrm{m}(\mathrm{N}=2)$. Cell wall is non-transparent and smoothsurfaced. The cell wall is approximately $2 \mu \mathrm{m}$ in thickness. 
Discussion.-Unnamed Form 5 differs from other spherical microfossils by having a single spine-like structure on the surface.

\section{Unnamed Form 6 \\ Figure 11.13}

Description.-Microfossil is vase-like in shape, $336 \mu \mathrm{m}$ in length and $248 \mu \mathrm{m}$ in width. The neck-like structure is $70 \mu \mathrm{m}$ in width and $50 \mu \mathrm{m}$ in length $(\mathrm{N}=1)$.

Discussion.-This specimen has a similar outline to the vaseshaped microfossil Cycliocyrillium torquata, which was reported from the Neoproterozoic Chuar Group (Porter et al., 2003, figs. 6-15). However, no reinforced margin as that in the vaseshaped microfossils (VSM) has been observed on the new specimen. VSM occur only in the Neoproterozoic. It is not appropriate to claim the relationship between the new specimen and real VSM, since only one specimen has been found in the new microbiota. Therefore, in the interim, it is considered as a new type of potential protist.

\section{Unnamed Form 7 \\ Figure 11.14, 11.15}

Description.-Vesicle with short and loosely distributed spinelike ornamentation on the cell surface. Spines do not branch. Cells are $25-101 \mu \mathrm{m}$ in diameter. Spines are $2-7 \mu \mathrm{m}(\mathrm{N}=2)$ in length.

Discussion.-Only two poorly preserved specimens have been recovered and they have been categorized under undetermined species temporarily.

\section{Acknowledgments}

This research project was supported by the National Natural Science Foundation of China (41502008), China Postdoctoral Science Foundation (2015M572221), and the National Basic Research Program of China (2011CB808800). We thank Z. Adam, M. Sharma, and another anonymous reviewer for their critical but inspiring comments on the manuscript. We thank the Editor B. Pratt, Associate Editor N. Butterfield, and Managing Editor S. Marcus for reviewing the manuscript and helping with format. We thank Xin Qian, Guozhen Xu, Tianyu Zhao, and Yan Zhang for their assistance during field works.

\section{References}

Adam, Z.R., Skidmore, M.L., and Mogk, D.W., 2016, Paleoenvironmental implications of an expanded microfossil assemblage from the Chamberlain Formation, Belt Supergroup, Montana, in MacLean, J.S., and Sears, J.W., eds., Belt Basin: Window to Mesoproterozoic Earth: Geological Society of America Special Paper, v. 522, p. 101-119. doi: 10.1130/2016.2522(04).

Agić, H., Moczydłowska, M., and Yin, L.M., 2015, Affinity, life cycle, and intracellular complexity of organic-walled microfossils from the Mesoproterozoic of Shanxi, China: Journal of Paleontology, v. 89, p. 28-50.

Andreeva, E.M., et al., 1966, Palaeopalynology: Trudy Vsesoyuznogo Neftyanogo Nauchno-Issledovatel'skogo Geologorazvedochnogo Instituta (VNIGNI), v. 141, p. 114-135.

Awramik, S.M., and Barghoorn, E.S., 1977, The Gunflint microbiota: Precambrian Research, v. 5, p. 121-142.

Butterfield, N.J., 2007, Macroevolution and macroecology through deep time: Palaeontology, v. 50, p. 41-55.
Butterfield, N.J., Knoll, A.H., and Swett, K., 1994, Paleobiology of the Neoproterozoic Svanbergfjellet Formation, Spitsbergen: Fossils and Strata, no. 34, Oslo, Scandanavian University Press, 84 p.

Campbell, I.H., and Allen, C.M., 2008, Formation of supercontinents linked to increases in atmospheric oxygen: Nature Geoscience, v. 1, p. 554-558.

Cao, F., 2005, A new type of primary unicellular microfossils from the chert of the Gaoyuzhuang Formation in Jixian County, Tianjin: Acta Geoscientica Sinica, p. 547-551. [in Chinese with English summary].

Cavalier-Smith, T., 2002, The phagotrophic origin of eukaryotes and phylogenetic classification of Protozoa: International Journal of Systematic and Evolutionary Microbiology, v. 52, p. 297-354.

Chu, X., Zhang, T., Zhang, Q., and Lyons, T.W., 2007, Sulfur and carbon isotope records from 1700 to $800 \mathrm{Ma}$ carbonates of the Jixian section, northern China: implications for secular isotope variations in Proterozoic seawater and relationships to global supercontinental events: Geochimica et Cosmochimica Acta, v. 71, p. 4668-4692.

Elenkin, A.A., 1936-1949. Monographia algarum cyanophycearum aquidulcium et terrestrium in finibus URSS inventarum [Sinezelenye vodorosli SSSR]: Moscow, AN SSSR, 1908 p. [in Russian].

Evitt, W.R., 1963, A discussion and proposals concerning fossil dinoflagellates, hystrichospheres and acritarchs: Proceedings of the National Academy of Seiences USA, v. 49, p. 298-302.

Gao, L.Z., Zhang, C.H., Yin, C.Y., Shi, X.Y., Wang, Z.Q., Liu, Y.M., Liu, P.J., Tang, F., and Song, B., 2008, SHRIMP zircon ages: basis for refining the chronostratigraphic classification of the Meso- and Neoproterozoic strata in North China old land: Acta Geoscientica Sinica, v. 29, p. 366-376. [in Chinese with English summary].

Gao, L.Z., Zhang, C.H., Liu, P.J., Ding, X.Z., Wang, Z.Q., and Zhang, Y.J., 2009, Recognition of Meso- and Neoproterozoic stratigraphic framework in north and south China: Acta Geoscientica Sinica, v. 30, p. 433-446. [in Chinese with English summary].

Guo, H., Du, Y.S., Zhou, L., Yang, J.H., and Huang, H., 2012, Isotopic composition of organic and inorganic carbon from the Mesoproterozoic Jixian Group, North China: implications for biological and oceanic evolution: Precambrian Research, v. 224, p. 169-183.

Holland, H.D., 2006, The oxygenation of the atmosphere and oceans: Philosophical Transactions of the Royal Society B: Biological Sciences, v. 361 , p. $903-915$.

Horodyski, R.J., and Donaldson, A.J., 1980, Microfossils from the Middle Proterozoic Dismal Lakes Groups, Arctic Canada: Precambrian Research, v. 11, p. $125-159$.

Hu, Y., and Fu, J., 1982, Micropalaeoflora from the Gaoshanhe Formation of Late Precambrian of Luonan, Shaanxi and its stratigraphic significance: Bulletin of the Xi'an Institute of Geology and Mineral Resources, Chinese Academy of Geological Science, v. 4, p. 102-113. [in Chinese with English summary].

Jankauskas, T.V., Mikhailova, N.S., and Hermann, T.N., eds., 1989, Precambrian Microfossils of the USSR: Leningrad, Nauka, 191 p. [in Russian].

Javaux, E.J., and Marshal, C.P., 2006, A new approach in deciphering early protist paleobiology and evolution: combined microscopy and microchemistry of single Proterozoic acritarchs: Review of Palaeobotany and Palynology, v. 139, p. 1-15.

Javaux, E.J., Knoll, A.H., and Walter, M.R., 2001, Morphological and ecological complexity in early eukaryotic ecosystems: Nature, v. 412, p. 66-69.

Javaux, E.J., Beghin, J., Houzay, J.P., and Blanpied, C., 2013, The "boring billion": an exciting time for early eukaryotes! (Goldschmidt Conference Abstracts): Mineralogical Magazine, 77, p. 1380. Kirchner, O., 1900, Shizophyceae, in Engler, A., and Prantl, K., eds., Die natürlichen Pflanzenfamilien: Leipzig, I Teil, Abteilung Ia, p. 115-121.

Knoll, A.H., 1982, Microfossils from the late Precambrian Draken Conglomerate, Ny Friesland, Svalbard: Journal of Paleontology, v. 56, p. 755-790.

Knoll, A.H., and Barghoorn, E.S., 1976, A Gunflint-type microbiota from the Duck Creek dolomite, Western Australia: Origins of life, v. 7, p. 417-423.

Knoll, A.H., and Calder, S., 1983, Microbiotas of the late Precambrian Ryssö Formation, Nordaustlandet, Svalbard: Palaeontology, v. 26, p. 467-496.

Knoll, A.H., and Golubic, S., 1979, Anatomy and taphonomy of a Precambrian algal stromatolite: Precambrian Research, v. 10, p 115-151.

Knoll, A.H., Swett, K., and Burkhardt, E., 1989, Paleoenvironmental distribution of microfossils and stromatolites in the Upper Proterozoic Backlundtoppen Formation, Spitsbergen: Journal of Paleontology, v. 63, p. $129-145$.

Knoll, A.H., Swett, K., and Mark, J., 1991, Paleobiology of a Neoproterozoic tidal flat/lagoonal complex: the Draken Conglomerate Formation, Spitsbergen: Journal of Paleontology, v. 65, p. 531-570.

Knoll, A.H., Javaux, E.J., Hewitt, D., and Cohen, P., 2006, Eukaryotic organisms in Proterozoic oceans: Philosophical Transactions of the Royal Society B: Biological Sciences, v. 361, p. 1023-1038.

Lamb, D.M., Awramik, S.M., Chapman, D.J., and Zhu, S.X., 2009, Evidence for eukaryotic diversification in the 1800 million-year-old Changzhougou Formation, North China: Precambrian Research, v. 173, p. 93-104. 
Lanier, W.P., 1989, Interstitial and peloid microfossils from the $2.0 \mathrm{Ga}$ Gunflint Formation: implications for the paleoecology of the Gunflint stromatolites: Precambrian Research, v. 45, p. 291-318.

Lee, S.J., and Golubic, S., 1998, Multi-trichomous cyanobacterial microfossils from the Mesoproterozoic Gaoyuzhuang Formation, China: paleoecological and taxonomic implications: Lethaia, v. 31, p. 169-184.

Li, H.K., Lu, S.N., Li, H.M., Sun, L.X., Xiang, Z.Q., Geng, J.Z., and Zhou, H.Y., 2009, Zircon and beddeleyite U-Pb precision dating of basic rock sills intruding Xiamaling Formation, North China: Geological Bulletin of China, v. 28, p. 1396-1404. [in Chinese with English summary].

Li, H.K., Zhu, S.X., Xiang, Z.Q., Su, W.B., Lu, S.N., Zhou, H.Y., Geng, J.Z., Li, S., and Yang, F.J., 2010, Zircon U-Pb dating on tuff bed from Gaoyuzhuang Formation in Yanqing, Beijing: further constraints on the new subdivision of the Mesoproterozoic stratigraphy in the northern North China Craton: Acta Petrologica Sinica, v. 26, p. 2132-2140. [in Chinese with English summary].

Li, H.K., Su, W.B., Zhou, H.Y., Geng, J.Z., Xiang, Z.Q., Cui, Y.R., Liu, W.C., and Lu, S.N., 2011, The base age of the Changchengian System at the northern North China Craton should be younger than 1670 Ma: constraints from zircon U-Pb LA-MC-ICPMS dating of a granite-porphyry dike in Miyun County, Beijing: Earth Science Frontiers, v. 18, p. 108-120. [in Chinese with English summary].

Li, H.K., Su, W.B., Zhou, H.Y., Xiang, Z.Q., Tian, H., Yang, L.G., Huff, W.D., and Ettensohn, F.R., 2014, The first precise age constraints on the Jixian System of the Meso- to Neoproterozoic standard Section of China: SHRIMP zircon U-Pb dating of bentonites from the Wumishan and Tieling formations in the Jixian section, North China Craton: Acta petrologica Sinica, v. 30, p. 2999-3012. [in Chinese with English summary].

Li, M., Liu, P., Yin, C., Tang, F., Gao, L., and Chen, S., 2012, Acritarchs from the Baicaoping Formation (Ruyang Group) of Henan: Acta Palaeontological Sinica, v. 51, p. 76-87. [in Chinese with English summary].

Licari, G.R., and Cloud, P.E., 1968, Reproductive structures and taxonomic affinities of some nannofossils from the gunflint iron formation: Proceedings of the National Academy of Sciences of the United States of America, v. 59, p. 1053-1060. https://www.ncbi.nlm.nih.gov/pmc/articles/ PMC224829/

Lu, S.N., and Li, H.M., 1991, A precise U-Pb single zircon age determination for the volcanics of Dahongyu Formation Changcheng system in Jixian: Bulletin of the Chinese Academy of Geological Sciences, v. 22, p. 137-146. [in Chinese with English summary].

Lu, S.N., Yang, C.L., Li, H.K., and Chen, Z.H., 2002, North China continent and Columbia supercontinent: Earth Science Frontiers, v. 9, p. 225-233. [in Chinese with English summary]

Lu, S.N., Li, H.K., Chen, Z.H., Yu, H.F., Jin, W., and Guo, K.Y., 2004, Relationship between Neoproterozoic cratons of China and the Rodinia Earth Science Frontiers, v. 11, p. 515-523. [in Chinese with English summary].

Mendelson, C.V., and Schopf, J.W., 1982, Proterozoic microfossils from the Sukhaya Tunguska, Shorikha, and Yudoma formations of the Siberian Platform, USSR: Journal of Paleontology, v. 56, p. 42-83.

Moczydłowska, M., Landing, E.D., Zang, W.L., and Palacios, T., 2011, Proterozoic phytoplankton and timing of Chlorophyte algae origins: Palaeontology, v. 54, p. 721-733.

Monty, C.L., 1976, The Origin and Development of Cryptalgal Fabrics, in Walter M.R., ed., Stromatolites: Developments in Sedimentology: Amsterdam, Elsevier, v. 20, p. 193-249.

Nägeli, C., 1849, Gattungen Einzelliger Algen, Physiologisch und Systematisch Bearbeitet: Zürich, F. Schulthess, 139 p.

Noffke, N., 2010, Geobiology: Microbial Mats in Sandy Deposits from the Archean Era to Today: Heidelberg, Springer, $196 \mathrm{p}$.

Oehler, D.Z., 1978, Microflora of the middle Proterozoic Balbirini Dolomite (McArthur Group) of Australia: Alcheringa, v. 2, p. 269-309.

Oehler, J.H., 1977, Microflora of the H.Y.C. Pyritic Shale Member of the Barney Creek Formation (McArthur Group), middle Proterozoic of northern Australia: Alcheringa, v. 1, p. 315-349. Peng, Y.B., Wang, D., and Yuan, X.L., 2007, Ultrastructure of spheroidal acritarchs from the Chuanlinggou Formation of the Changcheng System: Acta Micropalaeontologica Sinica, v. 24, p. 194-204. [in Chinese with English summary].

Peng, Y.B., Bao, H.M., and Yuan, X.L., 2009, New morphological observations for Paleoproterozoic acritarchs from the Chuanlinggou Formation, North China: Precambrian Research, v. 168, p. 223-232.

Planavsky, N.J., Reinhard, C.T., Wang, X.L., Thomson, D., Mcgoldrick, P., Rainbird, R.H., Johnson, T., Fischer, W.W., and Lyons, T.W., 2014, Low Mid-Proterozoic atmospheric oxygen levels and the delayed rise of animals: Science, v. 346, p. 635-638.

Porter, S.M., Meisterfeld, R., and Knoll, A.H., 2003, Vase-shaped microfossils from the Neoproterozoic Chuar Group, Grand Canyon: a classification guided by modern testate amoebae: Journal of Paleontology, v. 77, p. 409-429.
Ren, F.G., 1987, The essential character of volcanic-sedimentary rocks of Dahongyu Formation in Jixian: Bulletin Tianjin Institute of Geology and Mineral Resources, v. 16, p. 91-106. [in Chinese with English summary].

Santosh, M., 2010, A synopsis of recent conceptual models on supercontinent tectonics in relation to mantle dynamics, life evolution and surface environment: Journal of Geodynamics, v. 50, p. 116-133.

Schopf, J.W., 1968, Microflora of the Bitter Springs formation, late Precambrian, central Australia: Journal of Paleontology, v. 42, p. 651-688.

Schopf, J.W., and Blacic, J.M., 1971, New microorganisms from the Bitter Springs Formation (late Precambrian) of the north-central Amadeus Basin, Australia: Journal of Paleontology, v. 45, p. 925-960.

Sergeev, V.N., Knoll, A.H., and Grotzinger, J.P., 1995, Paleobiology of the Mesoproterozoic Billyakh Group, Anabar Uplift, Northern Siberia: Memoir (The Paleontological Society), v. 69, p. 1-37.

Sharma, M., 2006, Palaeobiology of Mesoproterozoic Salkhan Limestone, Semri Group, Rohtas, Bihar, India: systematics and significance: Journal of Earth System Science, v. 115, p. 67-98.

Shepeleva, E.D., 1963, Spore (?) Complexes in deposits of the Bavlinskoy Series of the Volga-Ural area, in Filimonova, A.B., and Archangelskaya A.D., eds., Spore-pollen Complexes and Stratigraphy of the Upper Proterozoic, Paleozoic and Mesozoic of the Volga-Uragarea and Central Asia: Trudy Vsesoyunogo Nauchno-Issledovatelskogo Geologorazvedochnogo Neftyanogo Instituta (VNIGNI), v. 37, p. 7-16.

Shi, M., Feng, Q.L., and Zhu, S.X., 2014, Biotic evolution and its relation with geological events in the Proterozoic Yanshan Basin, North China: Science China: Earth Sciences, v. 57, p. 903-918.

Stanier, R.Y., et al., 1978, Proposal to place the nomenclature of the cyanobacteria (blue-green algae) under the rules of the International Code of Nomenclature of Bacteria: International Journal of Systematic and Evolutionary Microbiology, v. 28, p. 335-336.

Su, W.B., Li, H.K., Huff, W.D., Ettensohn, F.R., Zhang, S.H., Zhou, H.Y., and Wan, Y.S., 2010, SHRIMP U-Pb dating for a K-bentonite bed in the Tieling Formation, North China: Chinese Science Bulletin, v. 55, p. 3312-3323. [in Chinese with English summary].

Sun, S.F., 2006, Microfossils in the Meso- Neoproterozoic Jixian section, China: Beijing, Geological Publishing House, p. 160 [in Chinese].

Teyssèdre, B., 2006, Are the green algae (phylum Viridiplantae) two billion years old?: Carnets de Géologie/Notebooks on Geology: 2006/03. http:// paleopolis.rediris.es/cg/CG2006_A03/index.html

Thuret, G., 1875, Essai de classification des Nostochinées: Annales des sciences naturelles (Botanique), v. 6, p. 372-382.

Timofeev, B.V., 1966, Micropaleophytological Investigations of Ancient Suites: Moscow, Nauka, $147 \mathrm{p}$.

Tobin, K.J., 1990, The paleoecology and significance of the Gunflint-type microbial assemblages from the Frere Formation (Early Proterozoic), Nabberu Basin, Western Australia: Precambrian Research, v. 47, p. 71-81.

Vorob'eva, N.G., Sergeev, V.N., and Petrov, P.Y., 2015, Kotuikan Formation assemblage: a diverse organic-walled microbiota in the Mesoproterozoic Anabar succession, northern Siberia: Precambrian Research, v. 256, p. 201-222.

Wettstein, R., 1924, Handbuch der Systematischen Botanik: Leipzig, Franz Deuticke, v. 1, 467 p.

Woese, C.R., and Fox, G.E., 1977, Phylogenetic structure of the prokaryotic domain: the primary kingdoms: Proceedings of the National Academy of Sciences, v. 74, p. 5088-5090.

Xiao, S., Knoll, A.H., Kaufman, A.J., Yin, L., and Zhang, Y., 1997, Neoproterozoic fossils in Mesoproterozoic rocks? Chemostratigraphic resolution of a biostratigraphic conundrum from the North China Platform: Precambrian Research, v. 84, p. 197-220.

Xing, Y.S., and Liu, G.Z., 1973, The Sinian microfossils from Yanshan area and its geological significance: Acta Geologica Sinica, v. 47, p. 1-51. [in Chinese with English summary].

Xu, D.B., Bai, Z.D., Wang, D.Z., Mei, M.X., and Li, Z.Z., 2002a, On sedimentary environment of the Dahongyu Formation in Xinglong region, Heibei: Journal of Stratigraphy, v. 26, p. 73-79. [in Chinese with English summary].

Xu, D.B., Wang, D.Z., Bai, Z.D., Mei, M.X., and Li, Z.Z., 2002b, Sedimentary environment and facies model of the Mesoproterozoic Chuanlinggou Formation in the Xinglong area, Hebei: Chinese Geology, v. 29, p. 167-171. [in Chinese with English summary].

Yan, Y.Z., 1982, Schizofusa from the Chuanlinggou Formation of Changcheng System in Jixian County: Bulletin Tianjin Institute of Geology and Mineral Resources, v. 6, p. 1-7. [in Chinese with English summary].

Yan, Y.Z., 1985, Preliminary research on microflora from Chuanlinggou Formation of Changcheng System in Jixian County: Bulletin Tianjin Institute of Geology and Mineral Resources., v. 12, p. 137-168. [in Chinese with English summary].

Yan, Y.Z., 1991, Shale-facies microflora from the Changzhougou Formation (Changcheng System) in Pangiapu region, Hebei, China: Acta Micropalaeontologica Sinica, v. 8, p. 183-191. [in Chinese with English summary]. 
Yan, Y.Z., and Liu, Z.L., 1993, Significance of eukaryotes organisms in the microfossil flora of Changcheng System: Acta Micropalaeontologica Sinica, v. 10, p. 167-180. [in Chinese with English summary].

Yan, Y.Z., and Liu, Z.L., 1998, Does Sangshuania represent eukaryotic algae or trace fossils?: Acta Micropalaeontologica Sinica, v. 15, p. 101-110. [in Chinese with English summary].

Yin, L.M., 1985, Microfossils from Precambrian rocks of the Dahongyu Formation of Jixian, North China: Acta Palaeontologica Sinica, v. 24, p. 111-115. [in Chinese with English summary].

Young, G.M., 2013, Secular changes at the Earth's surface; evidence from palaeosols, some sedimentary rocks, and palaeoclimatic perturbations of the Proterozoic Eon: Gondwana Research, v. 24, p. 453-467.

Zhang, P.Y., and Yan, X.L., 1984, Microfossil from the Gaoyuzhuang Formation in Laishui County, Hebei, China: Acta Geologica Sinica, v. 58, p. 196-203. [in Chinese with English summary].

Zhang, S.H., Li, Z.X., Evans, D., Wu, H.C., Li, H.Y., and Dong, J., 2012, Pre-Rodinia supercontinent Nuna shaping up: a global synthesis with new paleomagnetic results from North China: Earth and Planetary Science Letters, v. 353, p. $145-155$.

Zhang, Y., 1981, Proterozoic Stromatolite Microfloras of the Gaoyuzhuang Formation (Early Sinian: Riphean), Hebei, China: Journal of Paleontology, v. 55 , p. $485-506$.

Zhang, Y., 1984, A Gunflint type of microfossil assemblage from early Proterozoic stromatolitic cherts in China: Nature, v. 309, p. 547-549.
Zhang, Y., 1985, Stromatolitic microbiota from the Middle Proterozoic Wumishan Formation (Jixian Group) of the Ming Tombs, Beijing, China: Precambrian Research, v. 30, p. 277-302.

Zhang, Y., 1988, Proterozoic stromatolitic micro-organisms from Hebei, North China: cell preservation and cell division: Precambrian Research, v. 38 , p. $165-175$.

Zhang, Y., and Golubic, S., 1987, Endolithic microfossils (cyanophyta) from early Proterozoic stromatolites, Hebei, China: Acta Micropalaeontologica Sinica, v. 4, p. 1-12. [in Chinese with English summary].

Zhang, Y., Yang, C.Y., Yin, C.H., and Shao, C.X., 1995, Microbial mat communities and related sedimentary-geochemical aspects of the Mesoproterozoic Changcheng Group, Pangiiapu, Hebei, North China: Acta Micropalaeontologica Sinica, v. 12, p. 221-240. [in Chinese with English summary].

Zhang, Z.Y., and Li, Z.H., 1984, Noctidiurnal growth rhythm of filamentous cyanophytes from the Gaoyuzhuang Formation (Changcheng System) of North China: Chinese Science Bulletin, v. 29, p. 640 [in Chinese with English summary].

Zhang, Z.Y., and Liu, S., 1991, Post-burial contraction cracks in Precambrian acritarchs: Chinese Science Bulletin, v. 36, p. 400-403. [in Chinese with English summary].

Accepted 6 December 2016 